Article

\title{
Structure, DFT Calculations, and Magnetic Characterization of Coordination Polymers of Bridged Dicyanamido-Metal(II) Complexes
}

\author{
Franz A. Mautner ${ }^{1, *}$, Patricia Jantscher ${ }^{1}$, Roland C. Fischer ${ }^{2}$, Ana Torvisco ${ }^{2}{ }^{\oplus}$, Ramon Vicente ${ }^{3}$, \\ Tolga N. V. Karsili ${ }^{4}$ and Salah S. Massoud ${ }^{4, *(1)}$ \\ 1 Institut für Physikalische and Theoretische Chemie, Technische Universität Graz, A-8010 Graz, Austria \\ 2 Institut für Anorganische Chemie, Technische Universität Graz, Stremayrgasse 9/V, A-8010 Graz, Austria \\ 3 Departament de Quimica Inorganica I Organica, Universitat de Barcelona, Marti I Franques 1-11, \\ E-31321 Barcelona, Spain \\ 4 Department of Chemistry, University of Louisiana at Lafayette, P.O. Box 43700, Lafayette, LA 70504, USA \\ * Correspondence: mautner@tugraz.at (F.A.M.); ssmassoud@louisiana.edu (S.S.M.); \\ Tel.: +43-316-873-32270 (F.A.M.); +1-337-482-5672 (S.S.M.); Fax: +43-316-873-8225 (F.A.M.); \\ $+1-337-482-5672$ (S.S.M.)
}

Received: 23 April 2019; Accepted: 21 June 2019; Published: 2 July 2019

\begin{abstract}
Three coordination polymers of metal(II)-dicyanamido (dca) complexes with 4-methoxypyridine- $N$-oxide (4-MOP-NO); namely, catena- $\left[\mathrm{Co}\left(\mu_{1,5} \text {-dca }\right)_{2}(4-\mathrm{MOP}-\mathrm{NO})_{2}\right]$ (1), catena-[Mn $\left.\left(\mu_{1,5} \text {-dca }\right)_{2}(4-\mathrm{MOP}-\mathrm{NO})_{2}\right](2)$, catena-[Cd $\left.\left(\mu_{1,5}-\mathrm{dca}\right)_{2}(4-\mathrm{MOP}-\mathrm{NO})_{2}\right](3)$, and the mononuclear $\left[\mathrm{Cu}\left(\mathrm{K}^{1} \mathrm{dca}\right)_{2}(4-\mathrm{MOP}-\mathrm{NO})_{2}\right](4)$, were synthesized in this research. The complexes were analyzed by single crystal X-ray diffraction as well as spectroscopic methods (UV/vis, IR). The polymeric 1-D chains in complexes 1-3 were achieved by the doubly $\mu_{1,5}$-bridging dca ligands and the $O$-donor atoms of two axial 4-MOP-NO molecules in trans configuration around the distorted M(II) octahedral. On the other hand, the two "trans-axial" pyridine- $N$-oxide molecules in complexes 2 and $\mathbf{3}$ display opposite orientation (s-trans). The DFT (density functional theory) computational studies on the complexes 1-3 were consistent with the experimentally observed crystal structures. Compounds 1 and $\mathbf{2}$ display weak antiferromagnetic coupling between metal ions $(J=-10.8$ for $\mathbf{1}$ and -0.35 for 2 ).
\end{abstract}

Keywords: cobalt; manganese; cadmium; dicyanamide; coordination polymer; crystal structure; magnetic properties

\section{Introduction}

Small pseudohalide ions such as $\mathrm{N}_{3}{ }^{-}, \mathrm{NCS}^{-}, \mathrm{NCSe}^{-}$, and $\mathrm{NCO}^{-}$, as well as the longer dicyanamide ion $\mathrm{N}(\mathrm{CN})_{2}{ }^{-}$, are known to bind divalent $3 d$ and $4 d$ metal ions in a variety of ways, and thus have been extensively used as linkers between metal ions and the construction of coordination polymers (CPs) with different nuclearities, frameworks, and topologies [1-26]. This class of materials has some interesting applications in crystal engineering as they can be used to utilize molecular sensors [27], microporous materials for gas adsorption and storage [28-30], electrical conductivity [30], non-linear optical activity (NLO) [31,32], and catalytic reactions [33], as well as some polymeric chains, which have been constructed with $\mathrm{Zn}^{2+}$ and $\mathrm{Cd}^{2+}$ complexes, exhibit some potential applications as MOFs (metal-organic frameworks) [34,35]. The interaction of $\mathrm{Zn}(\mathrm{II})$ and $\mathrm{Cd}(\mathrm{II})$ with nitrogen heterocyclic coligands may lead to enhancement or quenching the fluorescence emission of the organic ligand $[9,10,36]$. In addition, CPs containing paramagnetic metal ions can serve as molecule-based magnets [37-40]. The bridged pseudohalide complexes have the capability to transmit the magnetic interaction between the paramagnetic metal centers across the bridged pseudohalides [1-8,10-14,18-24]. 
The dicyanamido complexes display a wide range of coordination modes with divalent metal ions ranging from simple coordination mode to the terminal or central amide group $\left(\mu_{1}\right.$ or $\left.\mu_{3}\right)[13,14,20,41]$ to complex modes including both of them. These modes, which are illustrated in Scheme 1 and have been previously summarized [10,14], include $\mu 2$ bonding: $\mu_{1,5}$ (end-to-end), $\mu_{1,1}$ (end-on), and $\mu_{1,3}$ [9-14,17-21,23,41]; $\mu 3$ bonding: $\mu_{1,1,5}$ and $\mu_{1,1,3}$ [14,18-20,24,25,42-49]; $\mu 4$ bonding: $\mu_{1,1,5,5}$ and $\mu_{1,1,3,5}$; and $\mu 5$ bonding: $\mu_{1,1,3,5,5}[14,18,24,25,45-49]$. The majority of bridged-dicyanamido-metal(II) complexes exhibit weak antiferromagnetic coupling [10-14,30,50,51]; however, in some cases, strong antiferromagnetic $[21,52]$ or weak ferromagnetic interactions have also been reported $[43,53]$.

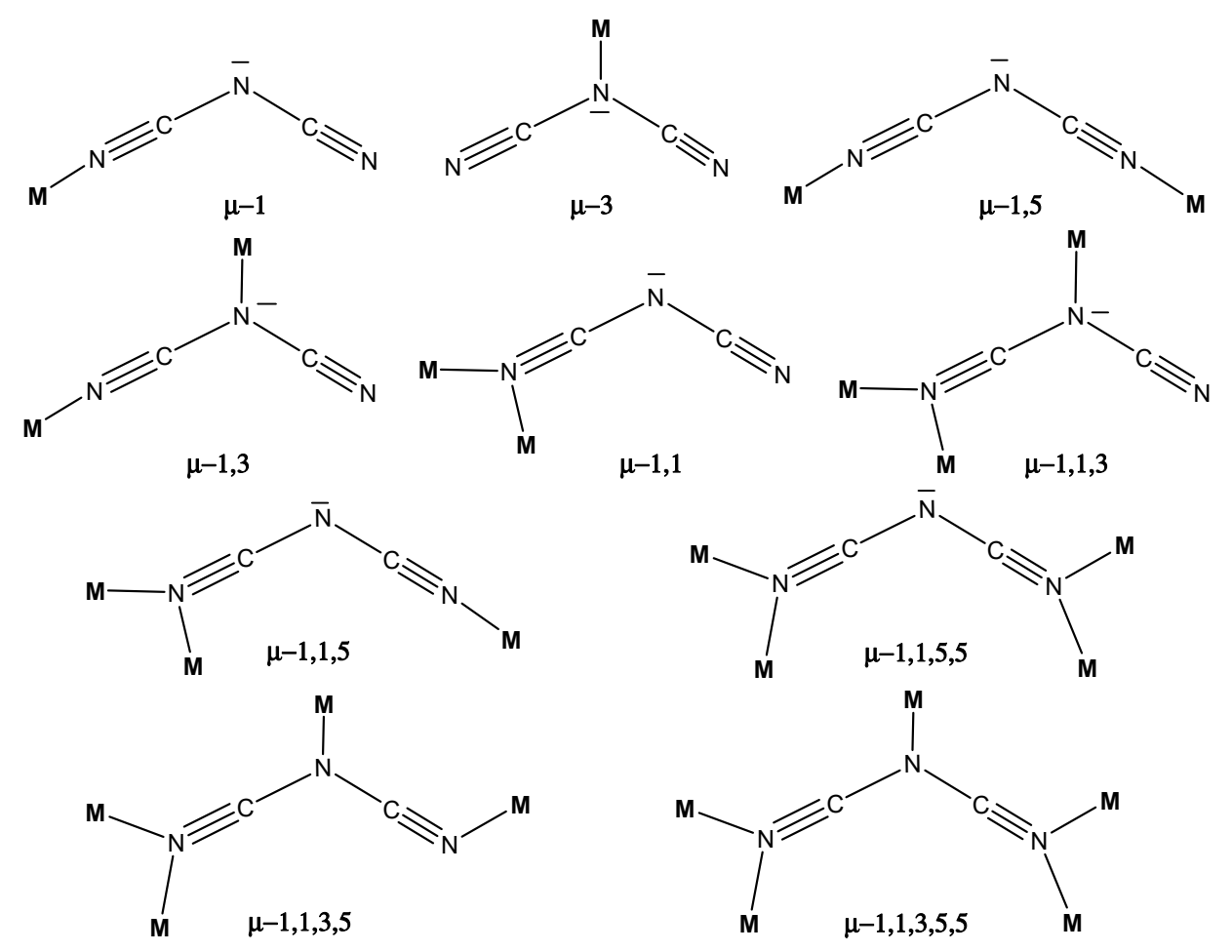

Scheme 1. Bonding modes of dicyanamide anion, $\mathrm{N}(\mathrm{CN})_{2}{ }^{-}$(dca), with metal ions.

In continuation of our effort to explore the coordination geometry and magnetic properties of pseudohalide metal(II) complexes containing pyridine and pyridine- $N$-oxide derivatives as coligands, the following study was undertaken. With pyridine- $\mathrm{N}$-oxide compounds, only two bonding modes (mono-dentate and bridging $\mu-\mathrm{O}, \mathrm{O}-\mathrm{NPR})[7,8,10,54-59]$ were found (Scheme 2). In the present study, the preparation and structural characterization of the 1D chain coordination polymers of 4-methoxypyridine- $\mathrm{N}$-oxide (4-MOP-NO) with dicyanamide, catena-[M $\left.\left(\mu_{1,5}-\mathrm{dca}\right)_{2}(4-\mathrm{MOP}-\mathrm{NO})_{2}\right](\mathrm{M}(\mathrm{II})$ $=\mathrm{Mn}(1), \mathrm{Co}(2), \mathrm{Cd}(3))$ and the monomeric $\left[\mathrm{Cu}(\mathrm{dca})_{2}(4-\mathrm{MOP}-\mathrm{NO})_{2}\right](4)$, are reported. Furthermore, compounds $\mathbf{1}$ and $\mathbf{2}$ were magnetically characterized and the results are compared to those derived from dicynamido-metal(II) compounds containing pyridyls.
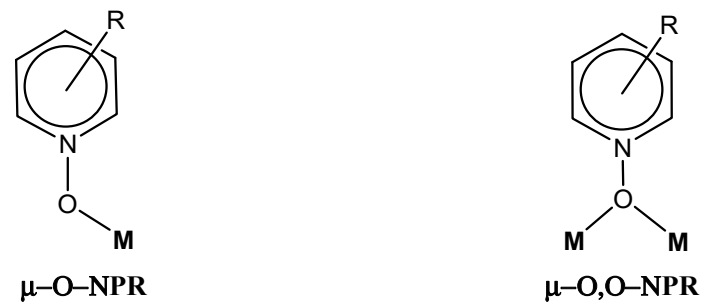

Scheme 2. Coordination bonding modes of pyridine- $N$-oxide derivatives (NOPR). 


\section{Discussion of the Results}

\subsection{Preparation and Spectroscopy (IR, UV/Vis) of Complexes}

The reaction of aqueous solutions of metal(II) nitrates with Nadca and 4-methoxypyridine- $\mathrm{N}$-oxide in 1:2:2 molar ratio resulted in the formation of the polymeric chains catena-[M( $\left.\left.\mu_{1,5}-\mathrm{dca}\right)_{2}(4-\mathrm{MOP}-\mathrm{NO})_{2}\right]$ $\{\mathrm{M}=\mathrm{Co}(\mathbf{1}), \mathrm{Mn}(2), \mathrm{Cd}(3)\}$ and the mononuclear complex [Cu(dca) $\left.)_{2}(4-\mathrm{MOP}-\mathrm{NO})_{2}\right](4)$, whereas in the analogous reaction of $\mathrm{Zn}(\mathrm{II})$ nitrate, catena- $\left[\mathrm{Zn}\left(\mu_{1,5}-\mathrm{dca}\right)_{2}\right]$ was separated, where the $\mathrm{ZnN}_{4}$ tetrahedra are linked via four single $\mu_{1,5}$-dca to neighboring metal centers to result in a square grid $2 \mathrm{D}$ layer system [60].

The dicyanamide anion shows characteristic IR absorption bands at $2286 \mathrm{~cm}^{-1}$ for $v_{\mathrm{s}}+v_{\text {as }}(\mathrm{N}-\mathrm{C})$, $2232 \mathrm{~cm}^{-1}$ for $v_{\mathrm{as}}(\mathrm{N} \equiv \mathrm{C})$, and $2179 \mathrm{~cm}^{-1}$ for $v_{\mathrm{s}}(\mathrm{N} \equiv \mathrm{C})$, respectively [61]. These vibrations were observed at 2290, 2232, and $2172 \mathrm{~cm}^{-1}$, respectively, for complex 1; at 2290, 2232, and $2172 \mathrm{~cm}^{-1}$, respectively, for 2; at 2287, 2225, and $2170 \mathrm{~cm}^{-1}$, respectively, for 3; and at 2292, 2241, and $2166 \mathrm{~cm}^{-1}$, respectively, for 4 . The absorption bands of the dca anion at $1344 \mathrm{~cm}^{-1}$ for $v_{\mathrm{as}}(\mathrm{N}-\mathrm{C}), 930 \mathrm{~cm}^{-1}$ for $v_{\mathrm{s}}(\mathrm{N}-\mathrm{C}), 664 \mathrm{~cm}^{-1}$ for $\delta(\mathrm{CNC}), 543 \mathrm{~cm}^{-1}$ for $\delta(\mathrm{NCN})$, and $529 \mathrm{~cm}^{-1}$ for $\delta(\mathrm{NCN})$ are covered by pyridine derivative ligand vibrations (Figures S1-S4 of Supplementary Material).

The UV/vis spectrum of the solid Co(II) compound 1 exhibits three absorption bands at 1550, 780, and $420 \mathrm{~nm}$ (Figure S5). For Co(II) in an octahedral environment, these bands refer to the electronic transitions ${ }^{4} \mathrm{~T}_{2 \mathrm{~g}}(\mathrm{~F}) \leftarrow{ }^{4} \mathrm{~T}_{2 \mathrm{~g}}(\mathrm{~F}),{ }^{4} \mathrm{~T}_{2 \mathrm{~g}}(\mathrm{P}) \leftarrow{ }^{4} \mathrm{~T}_{1 \mathrm{~g}}(\mathrm{~F})$, and ${ }^{4} \mathrm{~A}_{2 \mathrm{~g}} \leftarrow{ }^{4} \mathrm{~T}_{1 \mathrm{~g}}(\mathrm{~F})$, respectively. The corresponding spectrum of the $\mathrm{Cu}$ (II) complex 4 (diluted with $\mathrm{BaSO}_{4}$ ) shows a broad band centered around $1100 \mathrm{~nm}$ and two more bands at 588 and $266 \mathrm{~nm}$. The latter band is most likely results from the electronic transition of the coordinated ligand, whereas the two intense bands centered located at 588 and $1100 \mathrm{~nm}$ may be attributed to the electronic transitions ${ }^{2} \mathrm{~B}_{1 \mathrm{~g}} \rightarrow{ }^{2} \mathrm{~B}_{2 \mathrm{~g}}$ and ${ }^{2} \mathrm{~B}_{1 \mathrm{~g}} \rightarrow{ }^{2} \mathrm{E}_{\mathrm{g}}$, respectively, for $\mathrm{Cu}$ (II) in a square planar arrangement [62]. On the other hand, the electronic spectrum of catena-[Mn $\left.\left(\mu_{1,5}-\mathrm{dca}\right)_{2}(4-\mathrm{MOP}-\mathrm{NO})_{2}\right]$ (2) revealed the presence of a band at $378 \mathrm{~nm}$, due to $\mathrm{L} \rightarrow \mathrm{M}$ $\mathrm{CT}$, and un-resolvable broad bands over the visible region between 500 and $800 \mathrm{~nm}$, with a shoulder around $460 \mathrm{~nm}$. These bands are very common in Mn(II)- $d^{5}$ octahedral configuration as a result of spin forbidden transitions. The solid spectra of the three complexes are shown in Figures S5-S7.

\subsection{Crystal Structures}

Figures 1-3 represent plots of the polymeric chains and packing views for $\mathbf{1}, \mathbf{2}$, and $\mathbf{3}$, respectively. In these complexes, the metal(II) centers are coordinated by four $\mathrm{N}$ atoms of dicyanamide anions, which act in the bis- $\mu(1,5)$-bridging mode, and $\mathrm{O}$ atoms of two terminal 4-methoxypyridine- $\mathrm{N}$-oxide molecules in trans configuration. The $\mathrm{MN}_{4} \mathrm{O}_{2}$ chromophores form distorted octahedra, with $\mathrm{M}-\mathrm{O} / \mathrm{N}$ bond lengths in the 2.0571(9) to 2.1320(11) $\AA$ range for 1, in the 2.1639(14) to 2.2402(19) $\AA$ range for 2, and in the 2.2713(10) to 2.3303(12) Å range for 3. The bis- $\mu(1,5)$-bridging dicyanamides form polymeric chains of polyhedra. 


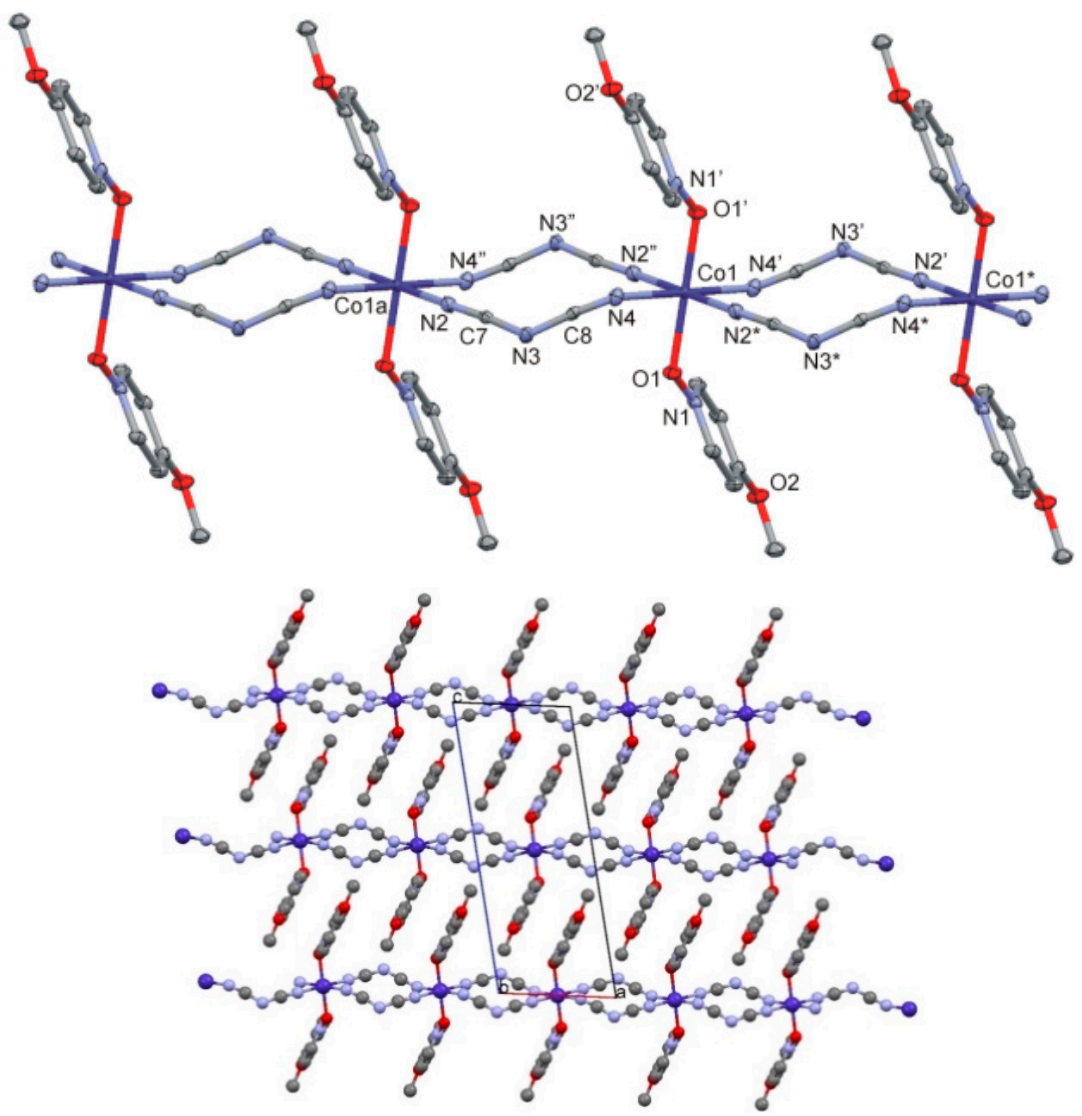

Figure 1. (top) One dimensional (1D) chain system of 1. Symmetry operations: (') 1-x,2-y,1-z; (") 2-x,2-y,1-z; (*)-1+x,y,z; (a) 1+x,y,z; (bottom) packing plot of 1 .

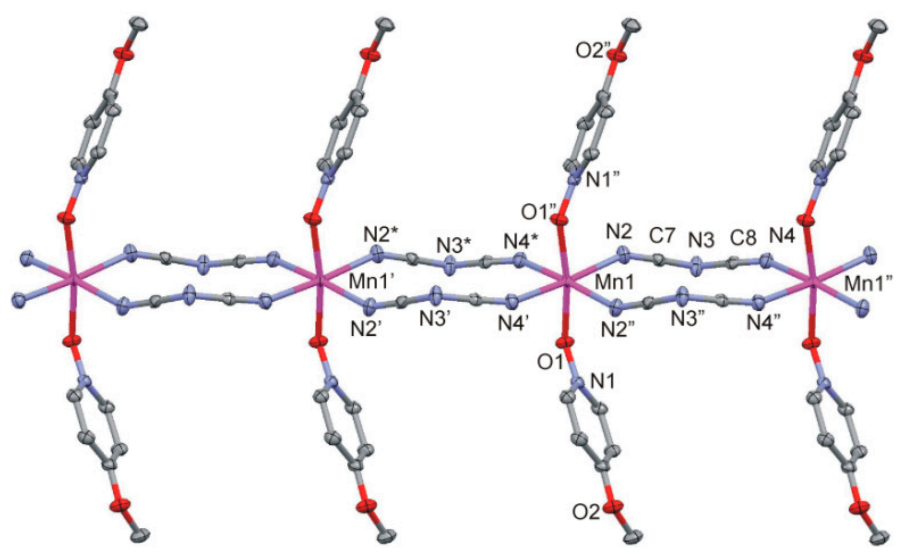

Figure 2. Cont. 


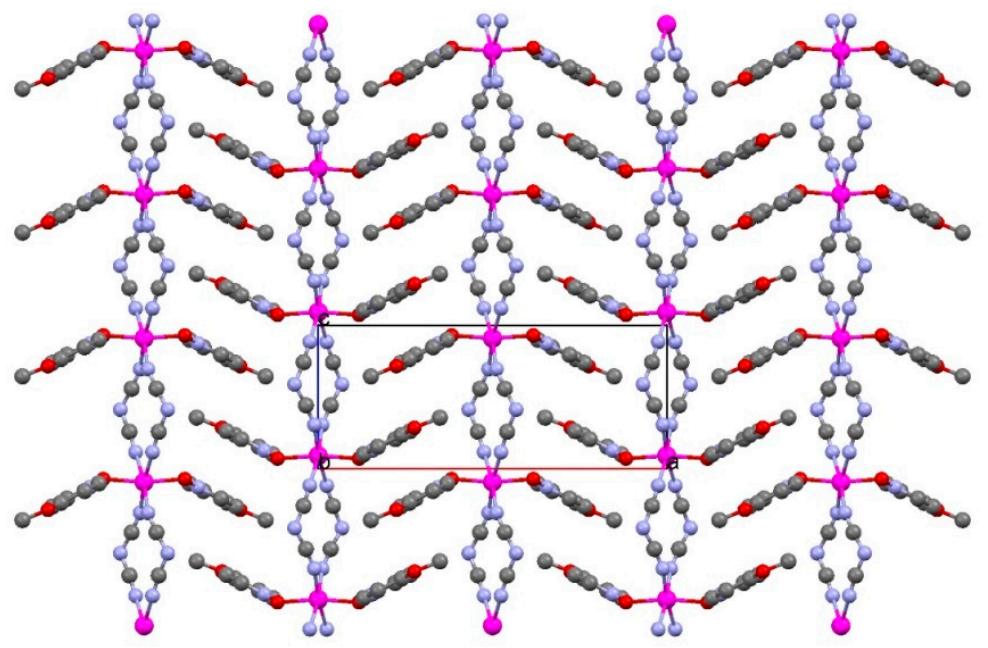

Figure 2. (top) One dimensional (1D) chain system of 2. Symmetry operations: (') 1-x,1-y,-z; (") $\left.1-\mathrm{x}, 1-\mathrm{y}, 1-\mathrm{z} ;{ }^{*}\right) \mathrm{x}, \mathrm{y},-1+\mathrm{z}$; (bottom) packing plot of 2 .

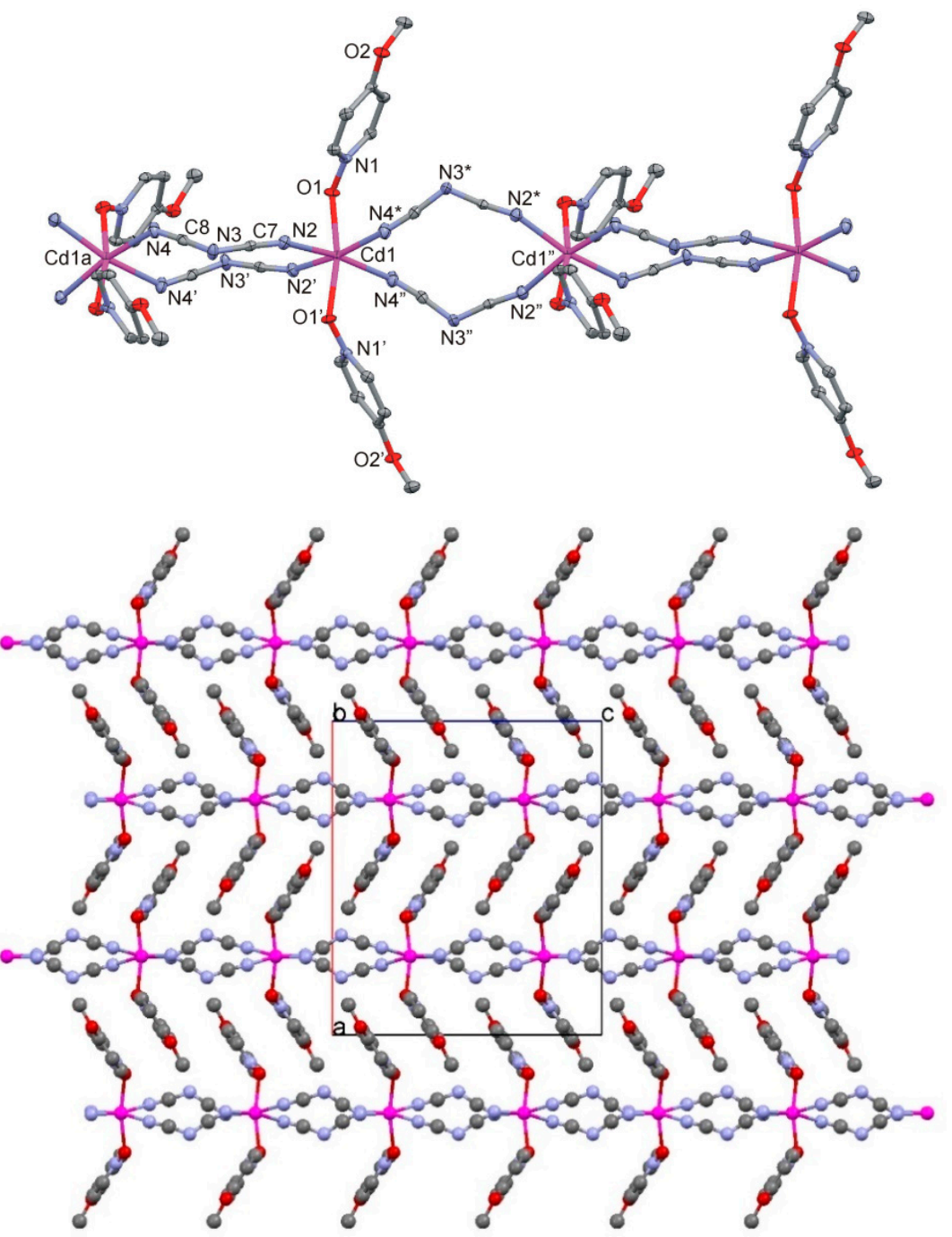

Figure 3. (top) One dimensional (1D) chain system of 3. Symmetry operations: (') 3/2-x,3/2-y,z; (") $\mathrm{x}, 3 / 2-\mathrm{y}, 1 / 2-\mathrm{z} ;\left(^{*}\right) 3 / 2-\mathrm{x}, \mathrm{y}, 3 / 2+\mathrm{z}$, (a) x,3/2-y,-1/2-z; (bottom) packing plot of 3 . 
The structures of complexes 2 and 3 are orthorhombic with space groups $\mathrm{P} 2{ }_{1} 2{ }_{1} 2$ (no. 18) and Pccn (no. 56), respectively, and their metal(II) centers have site symmetry 2, as the two "trans-axial" pyridine- $N$-oxide molecules are not ligated vertical to the "equatorial" $\mathrm{MN}_{4}$ (dca) plane. In the $\mathrm{Co}$ (II) complex, the pyridine- $N$-oxide molecules show the opposite orientation when viewed along the chain direction (s-trans, $\mathrm{N} 1-\mathrm{O} \cdots \mathrm{O} 1^{\prime}-\mathrm{N1}^{\prime}$ torsion angle is $-180^{\circ}$ ). In complexes 2 and 3, the pyridine- $\mathrm{N}$-oxide molecules have the same orientation when viewed along the chain direction (s-cis, $\mathrm{N}-\mathrm{O} \cdots \mathrm{O}^{\prime}-\mathrm{N}^{\prime}$ torsion angle is +131.6 and $-123.2^{\circ}$, respectively). Furthermore, in 3 , an alternative $\mathrm{CdN}_{4} \mathrm{O}_{2}$ octahedron in the

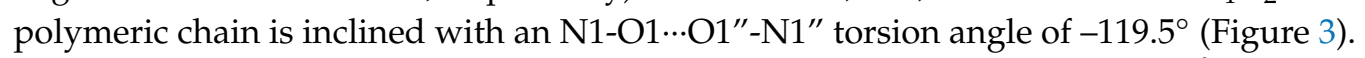

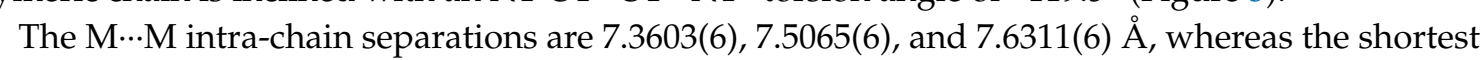

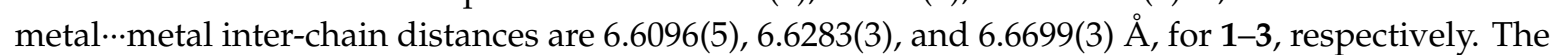
M-O-N bond angles of the 4-MOP-NO ligand molecules are in the range from 123.39(8) to 127.65(18) ${ }^{\circ}$. Their methoxy groups form synperiplanar $\mathrm{C}-\mathrm{O}-\mathrm{C}-\mathrm{C}$ torsion angles in the range from 3.2 to $5.8^{\circ}$.

It is interesting to mention that the 1D polymeric complexes under investigation; regardless, they have the same $\mathrm{MN}_{4} \mathrm{O}_{2}$ with distorted octahedra, they are not isostructural with those reported for the analogous $1 \mathrm{D}$ systems of catena- $\left[\mathrm{M}\left(\mu_{1,5}-\mathrm{dca}\right)_{2}(\mathrm{~L})_{2}\right](\mathrm{L}=4$-hydroxymethylpyridine or 3-aminopyridine $[10,63])$. The 1D polymeric complexes with these two coligands crystallize in the monoclinic system ( $\mathrm{P} 2{ }_{1} / \mathrm{c}$, space group no. 14), and their metal centers sit on the centers of inversion, which is also the case for the current $\mathrm{Co}$ (II) complex $\mathbf{1}$. In contrast to the $N$-coordinated 4-hydroxymethylpyridine and 3-aminopyridine ligands, the complexes 2 and 3 adopt different structural orientations. However, they are similar to the analogous $1 \mathrm{D}$ systems of catena-[M( $\left.\left(\mu_{1,5}-\mathrm{dca}\right)_{2}(\mathrm{~L})_{2}\right]$ ( $\mathrm{L}=4$-hydroxymethylpyridine or 3-aminopyridine) $[10,63]$, where the pyridine rings of adjacent 4-methoxypyridine- $N$-oxide molecules in 1-3 form non-covalent $\pi-\pi$ ring-ring interactions along the chain direction, as summarized in Table 1.

Table 1. Non-covalent $\pi-\pi$ ring-ring interactions in 1-3.

\begin{tabular}{|c|c|c|c|c|c|}
\hline Comp. & $\operatorname{Ring}(\mathrm{I}) \ldots \operatorname{Ring}(\mathrm{J})$ & Symmetry of J & $\mathrm{Cg} \ldots \mathrm{Cg}(\AA)$ & Alpha $\left({ }^{\circ}\right)$ & Cg(I)_perp (Å) \\
\hline \multirow[t]{2}{*}{1} & $\mathrm{Cg}($ py)...Cg(py) & {$[1-x,-1 / 2+y, 1 / 2-z]$} & $4.7136(8)$ & $1.85(6)$ & $3.2119(5)$ \\
\hline & $\mathrm{Cg}($ py)...Cg(py) & {$[1-x, 1 / 2+y, 1 / 2-z]$} & $4.7135(8)$ & $1.85(6)$ & $3.2118(5)$ \\
\hline \multirow[t]{2}{*}{2} & $\mathrm{Cg}($ py)...Cg(py) & {$[3 / 2-x,-1 / 2+y, 2-z]$} & $4.7115(12)$ & $2.57(10)$ & $3.3814(9)$ \\
\hline & $\mathrm{Cg}(\mathrm{py}) \ldots \mathrm{Cg}(\mathrm{py})$ & {$[3 / 2-x, 1 / 2+y, 2-z]$} & $4.7114(12)$ & $2.57(10)$ & $3.2329(9)$ \\
\hline \multirow[t]{2}{*}{3} & $\mathrm{Cg}($ py)...Cg(py) & {$[1-x,-1 / 2+y, 3 / 2-z]$} & $4.6548(8)$ & $0.61(6)$ & $3.2300(5)$ \\
\hline & $\mathrm{Cg}(\mathrm{py}) \ldots \mathrm{Cg}(\mathrm{py})$ & {$[1-x, 1 / 2+y, 3 / 2-z]$} & $4.6548(8)$ & $0.61(6)$ & $3.2652(5)$ \\
\hline
\end{tabular}

$\mathrm{Cg}(\mathrm{py})=$ centroid of pyridine ring $(\mathrm{N} 1, \mathrm{C} 1-\mathrm{C} 5) ; \mathrm{Cg} \ldots \mathrm{Cg}=$ distance between ring centroids $(<5 \AA)$; Alpha = dihedral angle between plane I and $\mathrm{J} ; \mathrm{Cg}(\mathrm{I}) \_$perp = perpendicular distance of $\mathrm{Cg}(\mathrm{I})$ on ring $\mathrm{J}$.

The copper(II) center of the mononuclear $\left[\mathrm{Cu}\left(\kappa^{1} \mathrm{dca}\right)_{2}(4-\mathrm{MOP}-\mathrm{NO})_{2}\right](4)$ (Figure 4$)$ sits on the center of inversion and is ligated by $\mathrm{N}$ atoms of the two terminal dicyanamide anions and $\mathrm{O}$ atoms of two 4-methoxypyridine- $\mathrm{N}$-oxide molecules. Its $\mathrm{CuN}_{2} \mathrm{O}_{2}$ chromophore has a trans-square planar geometry, with $\mathrm{Cu}-\mathrm{O} / \mathrm{N}$ bond lengths within the 1.924(13) to 1.9578(9) $\AA$ range. $\mathrm{N}(3)$ atoms of adjacent polyhedra are separated by 2.959(7) $\AA$ (Figure 4). The dicyanamide anions are disordered $(0.57(2) / 0.43(2)$ two-fold split occupancies). The $\mathrm{N}(1)-\mathrm{O}(1)-\mathrm{Cu}(1)$ bond angle is $118.39(6)^{\circ}$. The 4-methoxy-goup of the 4-MOP-NO molecule deviates by $3.2^{\circ}$ from its pyridine ring plane. The 4-MOP-NO molecule forms a $\mathrm{C}(6)-\mathrm{O}(2)-\mathrm{C}(3)-\mathrm{C}(4)$ torsion angle of $3.2^{\circ}$. The $\mathrm{N}(1)-\mathrm{O}(1)-\mathrm{Cu}(1)$ bond angle is $118.39(6)^{\circ}$. 

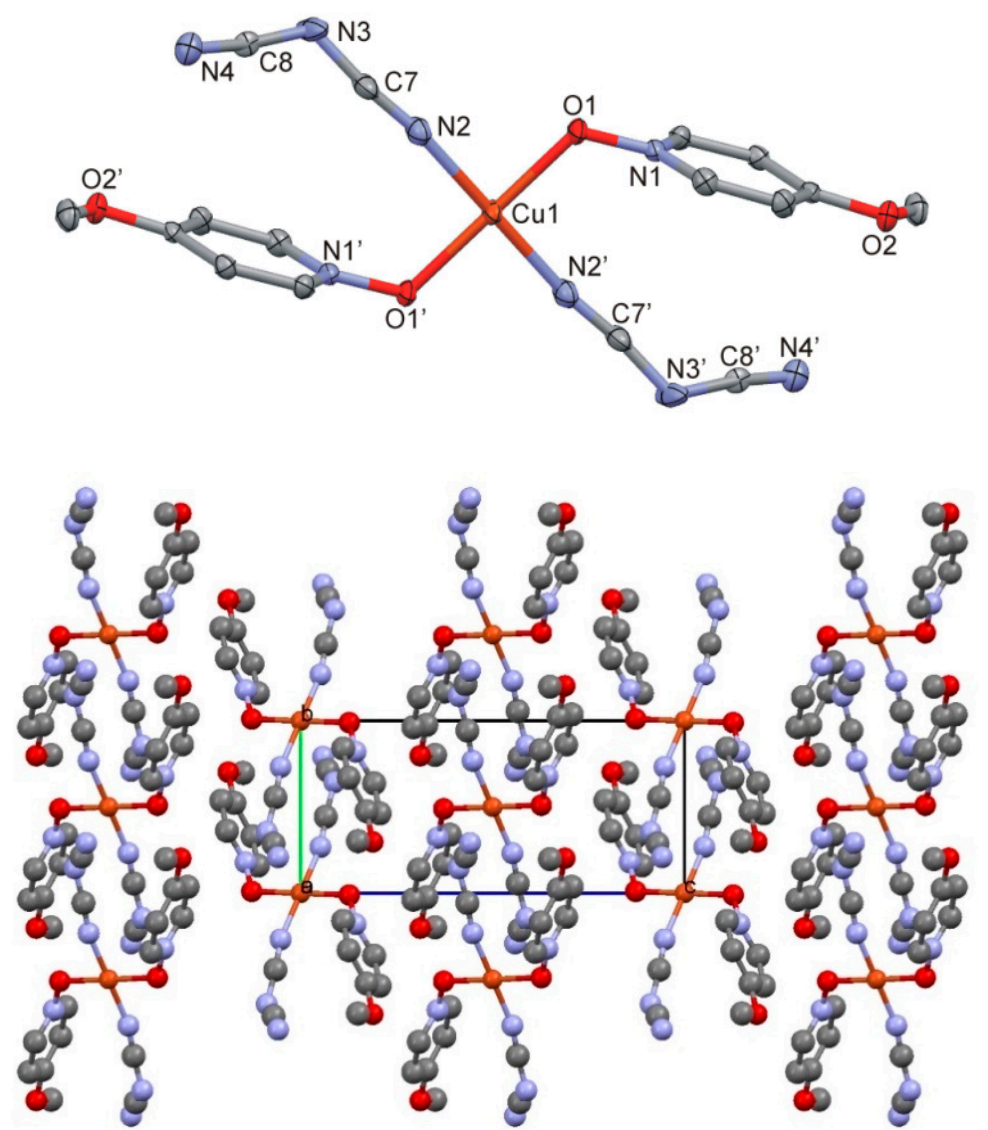

Figure 4. (top) Molecular plot of 4. Symmetry operations: (') 1-x,1-y,1-z; (bottom) packing plot of 4.

\subsection{Magnetic Data}

The magnetic susceptibility for catena-[Co $\left.\left(\mu_{1,5}-\mathrm{dca}\right)_{2}(4-\mathrm{MOP}-\mathrm{NO})_{2}\right](\mathbf{1})$ was measured in the temperature range of $2-299 \mathrm{~K}$, in a 5000 Oe dc field. The $\chi_{M} T$ versus $T$ plot for $\mathbf{1}$ is shown in Figure 5. The room temperature $\chi_{\mathrm{M}} \mathrm{T}$ value of $2.9 \mathrm{~cm}^{3} \mathrm{~mol}^{-1} \mathrm{~K}$ is much greater than the expected spin only value of $1.87 \mathrm{~cm}^{3} \mathrm{~mol}^{-1} \mathrm{~K}$ for $\mathrm{S}=3 / 2$, which results from the orbital contribution in Co(II) with $g$ values strongly deviating for 2.00. The $\chi_{M} T$ values decrease with decreasing the temperature and reaching a value of $1.11 \mathrm{~cm}^{3} \mathrm{~mol}^{-1} \mathrm{~K}$ at $2 \mathrm{~K}$. The decrease in the $\chi_{\mathrm{M}} \mathrm{T}$ values when the temperature decreases is partially attributed to antiferromagnetic intra-chain interactions, but this can be assumed to display minor exchange interactions, which are mediated by the $\mu_{1,5}$-bridging dicyanamido bridges. This result is in agreement with previously published experimental data and MO calculations [63-68]. Therefore, in order to obtain an approximate estimate for the coupling constant, $J$, the magnetic behavior of the $\mathrm{Co}(\mathrm{II})$-ion in axially distorted octahedral coordination may be well described with the effective spin $\mathrm{S}=1 / 2$ and strongly anisotropic $\mathrm{g}$ factor. The Hamiltonian for the Ising chain of Co(II) ions in $\mathbf{1}$ is given by Equation (1):

$$
\hat{H}=-J \sum_{i, j} s_{i, z} s_{j, z}+\mu_{B} \sum_{k} H \cdot \hat{g} \cdot s_{K} \cdot
$$




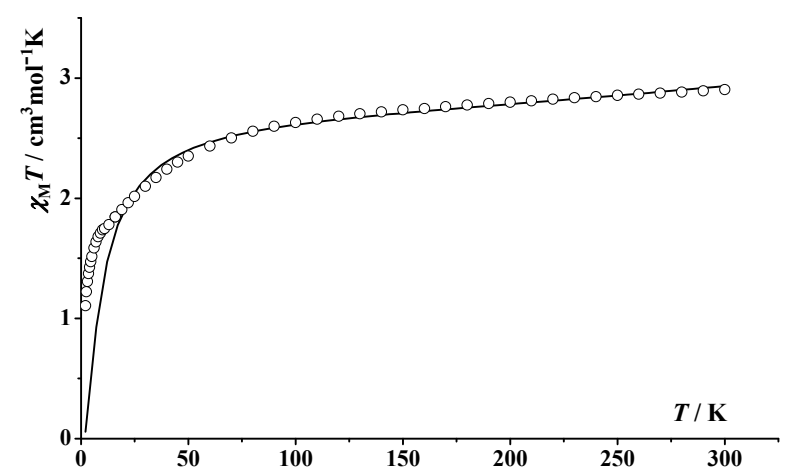

Figure 5. $\chi_{\mathrm{M}} \mathrm{T}$ vs. T Plot for catena-[Co( $\left.\left.\mu_{1,5}-\mathrm{dca}\right)_{2}(4-\mathrm{MOP}-\mathrm{NO})_{2}\right](\mathbf{1})$. The solid line shows the best fit obtained (see text).

The solution of this Hamiltonian for the parallel and perpendicular susceptibility in a magnetic field close to zero was derived by Fisher [69]:

$$
\begin{gathered}
\chi_{\|}=\frac{N_{A} \mu_{B}^{2} g_{\|}^{2}}{4 k \mathrm{~T}} \exp (J / 2 k \mathrm{~T}) \\
\chi_{\perp}=\frac{N_{A} \mu_{B}^{2} g_{\perp}^{2}}{2 J}\left\{\tanh (J / 4 k \mathrm{~T})+J /\left[4 k \mathrm{~T} \cosh ^{2}(J / 4 k \mathrm{~T})\right]\right\}
\end{gathered}
$$

For powder samples, the average susceptibility $\chi=\left(\chi_{\|}+2 \chi_{\perp}\right) / 3$ is measured. The experimental $\chi \mathrm{T}$ versus $\mathrm{T}$ data in the dc field of 5000 Oe were fitted with the Ising model over the temperature range of 10-300 K (Figure 5). The best fit parameters are as follows: $J=-10.8 \pm 0.4 \mathrm{~cm}^{-1}, \mathrm{~g}_{\|}=9.5 \pm 0.1$, and $\mathrm{g}_{\perp} \approx 0$.

The $\chi_{M}{ }^{-1}$ versus $T$ values for 1 are plotted in Figure 6 . The behavior of this compound is fully described by the Curie-Weiss law $\chi_{M}=C /(T-\theta)$ over the temperature range of 50-300 K, as indicated by the linear $\chi_{\mathrm{M}}{ }^{-1}$ versus $\mathrm{T}$ plot. The best fit of the magnetic susceptibility data with the Curie-Weiss law yielded $\mathrm{C}=2.99 \mathrm{~cm}^{3} \mathrm{Kmol}^{-1}$ and $\theta=-13.8 \mathrm{~K}$ values.

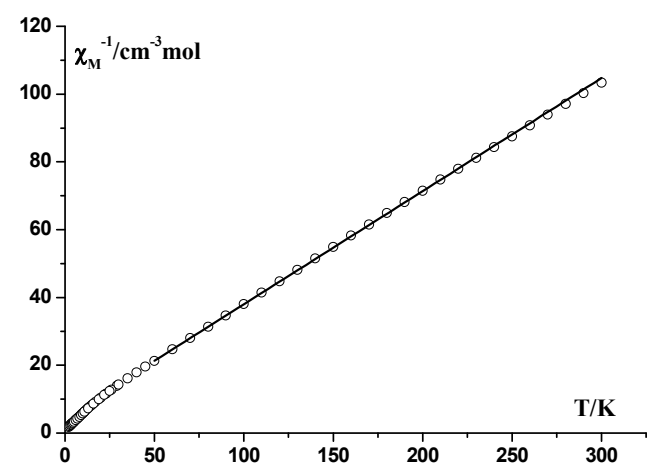

Figure 6. $\mathrm{XM}_{\mathrm{M}}^{-1}$ vs. T Plot for catena-[Co( $\left.\left.\mu_{1,5}-\mathrm{dca}\right)_{2}(4-\mathrm{MOP}-\mathrm{NO})_{2}\right](\mathbf{1})$. The Curie-Weiss law; the best fit is given as a solid line.

The magnetic susceptibility of the compound catena-[Mn $\left.\left(\mu_{1,5}-\mathrm{dca}\right)_{2}(4-\mathrm{MOP}-\mathrm{NO})_{2}\right]$ (2) was measured over the 2-300 K temperature range in a dc field of 3000 Oe. The plot of $\chi_{M}{ }^{T}$ versus $\mathrm{T}$ for $\mathbf{2}$ is illustrated in Figure 7. When the sample is cooled, the $\chi_{M} T$ values decrease slowly from $4.4 \mathrm{~cm}^{3} \mathrm{~K} \mathrm{~mol}^{-1}$ at $300 \mathrm{~K}$, followed by a more rapid decrease below $50 \mathrm{~K}$, and tends to zero at a low temperature. The $\chi_{M}$ values increase continuously throughout cooling. The overall magnetic behavior 
of $\mathbf{2}$ is consistent with a weak antiferromagnetically coupled system. The data were analyzed by the analytical expression of Equation (4) for an infinite chain of classical spins [70]:

$$
\chi=\left[\mathrm{Ng}^{2} \beta^{2} \mathrm{~S}(\mathrm{~S}+1) / 3 k \mathrm{~T}\right][(1+\mathrm{u}) /(1-\mathrm{u})]
$$

with $\mathrm{u}=\operatorname{coth}[J \mathrm{~S}(\mathrm{~S}+1) / k \mathrm{~T}]-k \mathrm{~T} / J \mathrm{~S}(\mathrm{~S}+1)$.

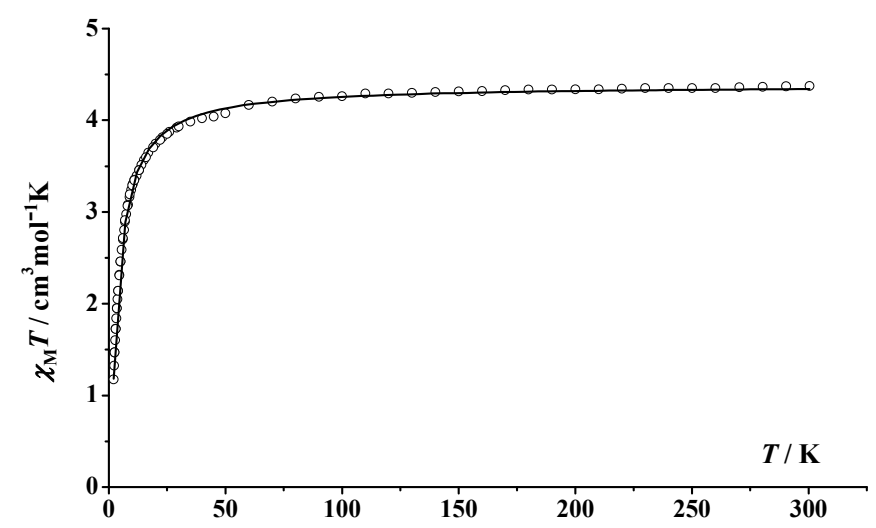

Figure 7. $\mathrm{X}_{\mathrm{M}}^{\mathrm{T}}$ vs. T Plot for catena-[Mn( $\mu_{1,5}$-dca $\left.)_{2}(4-\mathrm{MOP}-\mathrm{NO})_{2}\right](2)$. The solid line represents the best fit (see text).

The best-fit parameters produced $J=-0.35(1) \mathrm{cm}^{-1}$ and $\mathrm{g}=2.002(1)$. The weak antiferromagnetic interaction was revealed through the magnetization measurements at $2 \mathrm{~K}$ up to an external field of $5 \mathrm{~T}$. At high fields, the magnetization in $\mathrm{M} / \mathrm{N} \beta$ units indicates a quasi-saturated $\mathrm{S}=5 / 2$ system (Figure 8). The comparison of the overall shape of the plots with the Brillouin plot for a fully isolated $S=5 / 2$ system, $g=2.00$, shows that observed slower magnetization is consistent with a weak AF (antiferromagnetic) interaction. The resulting low $J$ value for $\mathbf{2}$ is fully in agreement with the determined weak antiferromagnetic coupling found in 1D bridged-dca-Mn(II) compounds [14,64,65,71].

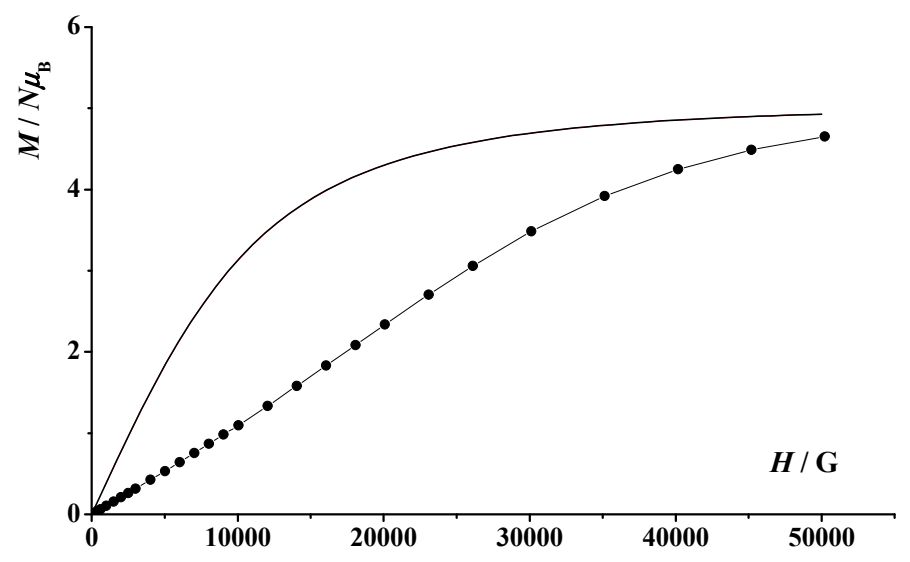

Figure 8. Plot of the magnetization in $2 \mathrm{~S}$ units measured at $2 \mathrm{~K}$ for compound 2. Solid line corresponds to the Brillouin function for fully isolated $S=5 / 2$ system, $g=2.00$.

\section{DFT Calculations}

Figure 9 shows the minimum energy geometry of the catena-[M $\left.\left(\mu_{1,5}-\mathrm{dca}\right)_{2}(4-\mathrm{MOP}-\mathrm{NO})_{2}\right]$ complexes, where $\mathrm{M}=\mathrm{Co}, \mathrm{Mn}$, or Cd complexes. The figure shows the $\mathrm{Co}(\mathrm{II})$ and $\mathrm{Mn}$ (II) complexes maintain the cis orientation of the 4-methoxypyridine- $N$-oxide ligands (located at two adjacent metal ions), which is in line with the experimentally observed crystal structure. In contrast, the corresponding $\mathrm{Cd}$ (II) complex shows a trans orientation for the 4-methoxypyridine- $N$-oxide ligands, which again is consistent with the experimentally observed crystal structure. 

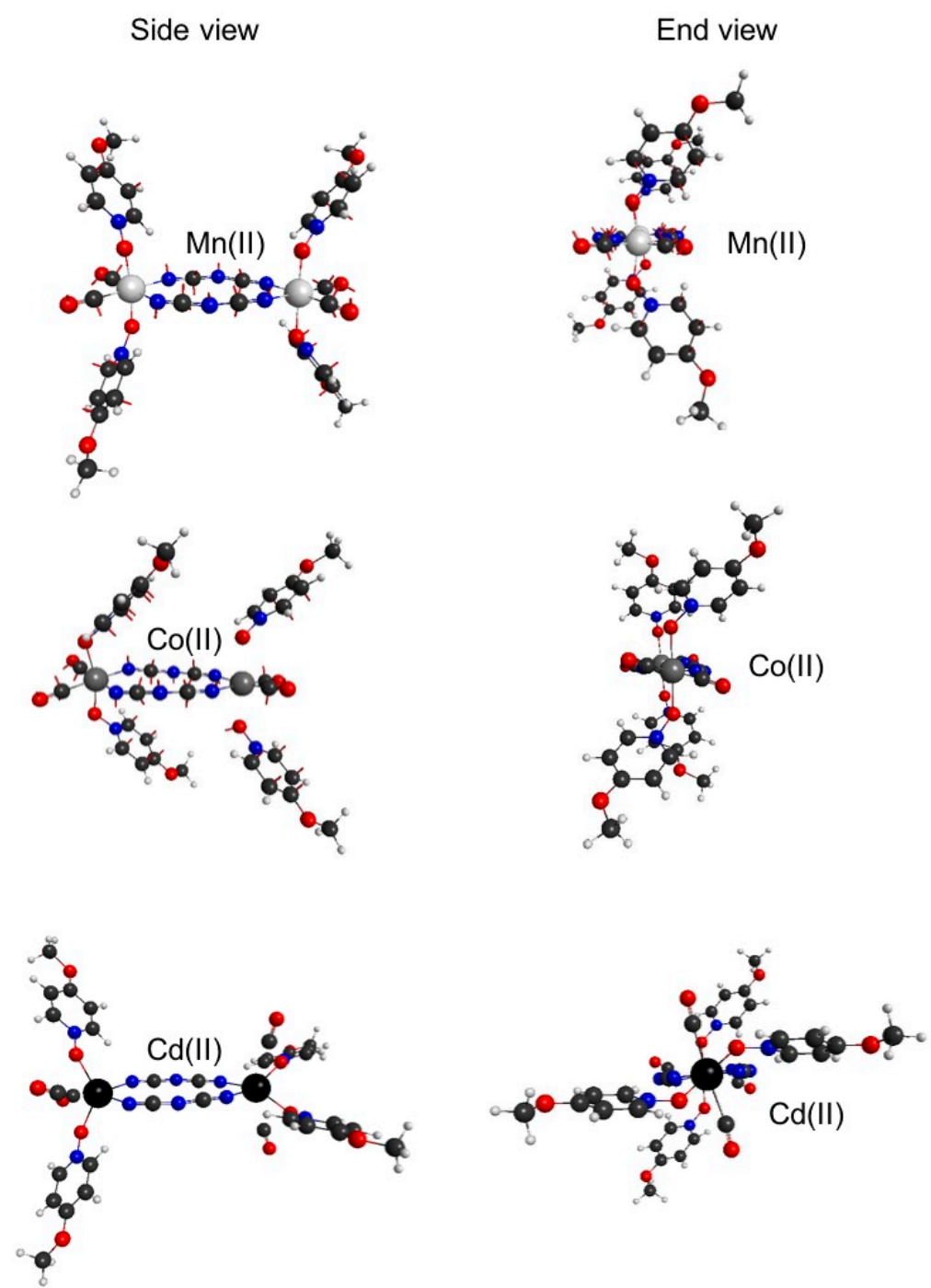

Figure 9. The global minimum energy geometries associated with the 1, 2, and 3 structures.

In order to quantify these observations, potential energy (PE) profiles were computed along the oxygen-metal-metal-oxygen dihedral (see molecular inset for highlighted dihedral angle); these are given in Figure 10. The PE profiles show very distinct profiles, in which the Co(II) and Mn(II) complexes reveal minima at $\phi \sim 0^{\circ}$, wherein the 4-methoxypyridine- $N$-oxide ligands maintain a cis conformation. In the $\mathrm{Cd}(\mathrm{II})$ complex, a global minimum is observed at $\phi \sim 50^{\circ}$, which constitutes a trans conformation of the 4-methoxypyridine- $N$-oxide ligands. 

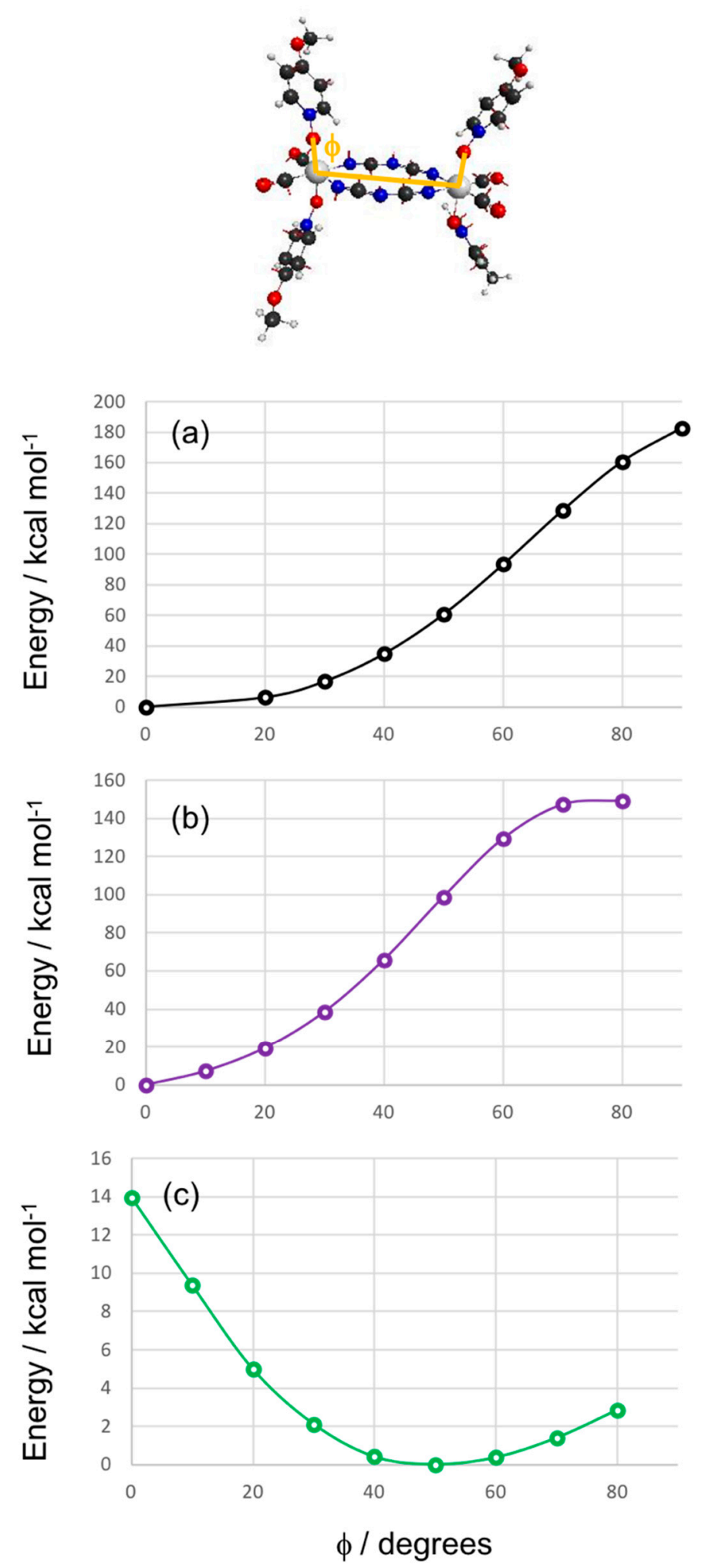

Figure 10. Potential energy profiles along the $\phi$ dihedral angle, which is defined at the top of the structure of (a) Mn(II), (b) Co(II), and (c) Cd(II) complexes of 2, 1, and 3, respectively.

The aforementioned theoretical results can be understood by considering the relative strength associated with the bridging dca when bound to $\mathrm{Co}, \mathrm{Mn}$, or $\mathrm{Cd}$. In the case of $\mathrm{Co}$ and $\mathrm{Mn}$, the strong $d$-orbital overlap of the metal center and the dca ligand maintains a rigid bonding arrangement about the bridging ligand. In contrast, the somewhat longer $\mathrm{Cd}$-dca bond leads to a reduction in the d-orbital 
overlap, thus weakening the rigidity about the Cd-dca moiety. This weakening in the d-electron overlap inevitably leads to high amplitude motion around the bridging ligand. In fact, this result is in complete agreement with the observed $\mathrm{M}-\mathrm{ON}$ bond distances, $\mathrm{M}(1)-\mathrm{O}\left(1^{\prime}\right): 2.0571,2.1639$, and $2.2713 \AA$ for $\mathrm{M}=\mathrm{Co}, \mathrm{Mn}$, and $\mathrm{Cd}$, respectively.

Further, in order to assess the short-range antiferromagnetic coupling of $\mathbf{1}$ and $\mathbf{2}$, two additional computations were performed. Although the returned calculations explore the short-range magnetic effect, the results are strikingly consistent with the experimental results. These are comprised of computing the ground state minimum energy of both species in their high-spin configurations, in which each Co(II) or Mn(II) center of $\mathbf{1}$ and $\mathbf{2}$, respectively, contained a quartet and sextet spin-symmetry, respectively. This high-spin symmetry configuration was then compared to the minimum energy geometry of the low-spin singlet spin-symmetry analogues.

In complexes 1 and 2, the localized quartet or sextet spin-symmetry on both $\mathrm{Co}$ (II) or $\mathrm{Mn}$ (II) centers, one with $\alpha$ spins and the other with $\beta$ spins (doublet symmetry in both cases), returns a lower energy than that of the low-spin, single-spin configuration (see Table S1 in Supplementary Materials section for the results of these calculations). This indicates that the alignment of the electrons in an anti-ferromagnetic arrangement with anti-parallel spins on the distinct $\mathrm{Co}$ (II) or $\mathrm{Mn}$ (II) centers is energetically favorable over the corresponding low-spin alignment of electrons. This agrees well with the experimental observations, which shows anti-ferromagnetic coupling for both $\mathbf{1}$ and $\mathbf{2}$.

\section{Conclusions}

To conclude, two categories of coordination polymers, doubly bridged by the terminal nitriles of dicyanamide (dca), of the structural formula catena-[M( $\left.\left.\mu_{1,5}-\mathrm{dca}\right)_{2}(4-\mathrm{MOP}-\mathrm{NO})_{2}\right](\mathrm{M}=\mathrm{Co}, \mathbf{1} ; \mathrm{Mn}, 2 ; \mathrm{Cd}, \mathbf{3})$ and a mononuclear $\left[\mathrm{Cu}(\mathrm{dca})_{2}(4-\mathrm{MOP}-\mathrm{NO})_{2}\right]$ were synthesized and structurally characterized based on 4-methoxypyridine- $\mathrm{N}$-oxide (4-MOP-NO). In the $\mathrm{CP}$ complexes, the polymeric $1 \mathrm{D}$ chains were achieved by the doubly $\mu_{1,5}$-bridging dca ligands and the $O$-donor atoms of the two axial 4-MOP-NO molecules are in trans configuration around the distorted $\mathrm{M}(\mathrm{II})$ octahedral. The trans-orientation adapted in title complexes, 1-3 are very similar to those observed in the corresponding CPs, catena-[M( $\left.\left.\mu_{1,5}-\mathrm{dca}\right)_{2}(\mathrm{~L})_{2}\right]$, where $\mathrm{L}=4$-hydroxymethylpyridine or 3-aminopyridine and $\mathrm{M}=\mathrm{Co}, \mathrm{Mn}, \mathrm{Cu}, \mathrm{Zn}$, or $\mathrm{Cd}[10,63]$. As in these structures, the adjacent pyridine rings of $\mathbf{1 - 3}$ also constitute extra stability through the non-covalent $\pi-\pi$ ring-ring interactions along the chain direction. The adaption of these configurations seem to be more common and unified in this class of compounds $[15,62,63,65,72,73]$. As a consequence of the long intramolecular distances between paramagnetic metal ions linked by $\mu_{1,5}$-dca coordination modes, the complexes 1 and $\mathbf{2}$ display weak antiferromagnetic coupling (small $|J|$ values) [63,65,72-76].

\section{Experimental}

\subsection{Materials and Physical Measurements}

All materials used for the preparation of the compounds were of reagent grade quality. A Bruker Alpha P with a platinum-ATR-cap was used for the measurement of the IR spectra of the solid complexes. UV/vis-NIR spectra of the cobalt(II) and copper(II) complexes were recorded with an LS950 Lambda-spectrometer (Perkin-Elmer, Waltham, MA, USA). Elemental microanalyses (CHN) were measured with an Elementar Vario EN3 analyzer. X-ray powder patterns of the bulk material were recorded with a D8 Advance diffractometer (Bruker-AXS, Billerica, MA, USA) (Figures S8-S11). Magnetic data of polycrystalline solid samples of $\mathbf{1}$ and $\mathbf{2}$ were recorded with a MPMS-XL SQUID magnetometer (Quantum Design, San Diego, CA, USA) at the Magnetic Measurements Unit of the Universität de Barcelona. Pascal's constants were applied for diamagnetic corrections. 


\subsection{Preparation of the Compounds}

\subsubsection{Preparation of Catena- $\left[\mathrm{M}\left(\mu_{1,5}-\mathrm{dca}\right)_{2}(4-\mathrm{MOP}-\mathrm{NO})_{2}\right](\mathbf{1}-3)$}

A similar procedure was used to prepare the complexes catena-[M( $\left.\left(\mu_{1,5}-\mathrm{dca}\right)_{2}(4-\mathrm{MOP}-\mathrm{NO})_{2}\right](\mathbf{1}-\mathbf{3})$ $(\mathrm{M}=\mathrm{Co}, 1 ; \mathrm{M}=\mathrm{Mn}, 2 ; \mathrm{M}=\mathrm{Cd}, 3)$. A mixture of metal(II) nitrate hexahydrate, $\mathrm{M}\left(\mathrm{NO}_{3}\right)_{2} \cdot 6 \mathrm{H}_{2} \mathrm{O}$ (1 mmol), $\mathrm{NaN}(\mathrm{CN})_{2}(0.18 \mathrm{~g}, 2 \mathrm{mmol})$, and 4-methoxypyridine- $\mathrm{N}$-oxide $(0.19 \mathrm{~g}, 2 \mathrm{mmol})$ was dissolved in $\mathrm{H}_{2} \mathrm{O}(50 \mathrm{~mL})$. The resulting solution, which was heated up to $70{ }^{\circ} \mathrm{C}$ and stirred for $30 \mathrm{~min}$, was then filtered and the clear solution was slowly concentrated in an open glass beaker to crystallize at approximately $300 \mathrm{~K}$ (room temperature). After approximately two days, the well-shaped resulting needles were filtered off and dried in air.

Catena-[Co $\left.\left(\mu_{1,5}-d c a\right)_{2}(4-M O P-N O)_{2}\right]$ (1): pink needles were obtained (yield: $0.26 \mathrm{~g}, 59 \%$ ). Characterization: Anal. calcd for $\mathrm{C}_{16} \mathrm{H}_{16} \mathrm{CoN}_{8} \mathrm{O}_{4}(441.28 \mathrm{~g} / \mathrm{mol}): \mathrm{C}, 43.6 ; \mathrm{H}, 3.2 ; \mathrm{N}, 25.4 \%$ Found: C, 43.7; H, 3.1; N, 25.3\%. IR (ATR, cm $\left.{ }^{-1}\right): 3118(\mathrm{w}), 3085(\mathrm{w}), 3043(\mathrm{w}), 2287(\mathrm{~m}), 2238(\mathrm{~m}), 2175(\mathrm{~s})$, $1624(\mathrm{~m}), 1566(\mathrm{w}), 1494(\mathrm{~s}), 1441(\mathrm{~m}), 1337(\mathrm{~m}), 1287(\mathrm{~m}), 1242(\mathrm{w}), 1209(\mathrm{~s}), 1182(\mathrm{~m}), 1114(\mathrm{w}), 1036(\mathrm{w})$, $1009(\mathrm{~m}), 935(\mathrm{w}), 856(\mathrm{~m}), 756(\mathrm{~s}), 662(\mathrm{~m}), 527(\mathrm{~m}), 502(\mathrm{~m}), 421(\mathrm{w})$.

Catena-[Mn $\left.\left(\mu_{1,5}-d c a\right)_{2}(4-M O P-N O)_{2}\right]$ (2): tint yellow needles (yield: $\left.0.29 \mathrm{~g}, 66 \%\right)$. Characterization: Anal. calcd for $\mathrm{C}_{16} \mathrm{H}_{14} \mathrm{MnN}_{8} \mathrm{O}_{4}(437.29 \mathrm{~g} / \mathrm{mol})$ : C, 43.9; H, 3.2; N, 25.6\%. Found: C, 43.7; $\mathrm{H}, 3.1 ; \mathrm{N}$, 25.8\%. $3115(\mathrm{w}), 3041(\mathrm{w}), 2290(\mathrm{~m}), 2232(\mathrm{~m}), 2172(\mathrm{~s}), 1624(\mathrm{~m}), 1564(\mathrm{w}), 1495(\mathrm{~s}), 1440(\mathrm{~m}), 1342(\mathrm{~m})$, $1288(\mathrm{~m}), 1214(\mathrm{~s}), 1209(\mathrm{~s}), 1112(\mathrm{w}), 1034(\mathrm{w}), 1010(\mathrm{~m}), 934(\mathrm{w}), 853(\mathrm{~m}), 759(\mathrm{~s}), 660(\mathrm{w}), 522(\mathrm{~m})$, $489(\mathrm{~m}), 412(\mathrm{w})$.

Catena- $\left[C d\left(\mu_{1,5}-d c a\right)_{2}(4-M O P-N O)_{2}\right]$ (3): colorless needle (yield: $\left.0.31 \mathrm{~g}, 63 \%\right)$. Characterization: Anal. calcd for $\mathrm{C}_{16} \mathrm{H}_{14} \mathrm{CdN}_{8} \mathrm{O}_{4}(494.76 \mathrm{~g} / \mathrm{mol}): \mathrm{C}, 38.8 ; \mathrm{H}, 2.9 ; \mathrm{N}, 22.6 \%$. Found: $\mathrm{C}, 38.6 ; \mathrm{H}, 2.8 ; \mathrm{N}$, 22.8\%. $3115(\mathrm{w}), 3051(\mathrm{w}), 2292(\mathrm{~m}), 2241(\mathrm{~m}), 2166(\mathrm{~s}), 1624(\mathrm{~m}), 1569(\mathrm{w}), 1499(\mathrm{~s}), 1460(\mathrm{w}), 1439(\mathrm{~m})$, 1355 (m), 1300 (s), 1257 (m), 1198 (s), 1118 (w), 1015 (s), 924 (w), 855 (s), 756(s), 661 (w), 546 (w), 509 (m), $461(\mathrm{~m}), 411(\mathrm{w})$.

\subsubsection{Synthesis of $\left[\mathrm{Cu}(\mathrm{dca})_{2}(4-\mathrm{MOP}-\mathrm{NO})_{2}\right](4)$}

A procedure similar to that described above was used with $\mathrm{Cu}\left(\mathrm{NO}_{3}\right)_{2} \cdot 3 \mathrm{H}_{2} \mathrm{O}$, where green needle shaped crystals of 4 were obtained (yield: $0.26 \mathrm{~g}, 58 \%$ ). Characterization: Anal. calcd for $\mathrm{C}_{16} \mathrm{H}_{14} \mathrm{CuN}_{8} \mathrm{O}_{4}(445.90 \mathrm{~g} / \mathrm{mol}): \mathrm{C}, 43.1 ; \mathrm{H}, 3.2 ; \mathrm{N}, 25.1$. Found: $\mathrm{C}, 43.0 ; \mathrm{H}, 3.2 ; \mathrm{N}, 25.0 \%$. IR (ATR, $\left.\mathrm{cm}^{-1}\right)$ : $3115(\mathrm{w}), 3051(\mathrm{w}), 2292(\mathrm{~m}), 2241(\mathrm{~m}), 2166(\mathrm{~s}), 1624(\mathrm{~m}), 1569(\mathrm{w}), 1499(\mathrm{~s}), 1460(\mathrm{w}), 1439(\mathrm{~m})$, $1355(\mathrm{~m}), 1300(\mathrm{~s}), 1257(\mathrm{~m}), 1198(\mathrm{~s}), 1118(\mathrm{w}), 1015(\mathrm{~s}), 924(\mathrm{w}), 855(\mathrm{~s}), 756(\mathrm{~s}), 661(\mathrm{w}), 546(\mathrm{w}), 509(\mathrm{~m})$, $461(\mathrm{~m}), 411(\mathrm{w})$.

\subsection{X-Ray Single Crystal Measurements of 1-4}

Single-crystal data of 1-4 were measured on an APEX II CCD diffractometer (Bruker-AXS). Table 2 summarizes crystallographic data, intensity data collection, and structure refinement specifications. Data collections were performed at $100(2) \mathrm{K}$ with Mo-K $\alpha$ radiation $(\lambda=0.71073 \AA)$; computer programs APEX and SADABS $[77,78]$ were used for data reduction, LP, and absorption corrections. The program library SHELX $[79,80]$ was used for solution (direct methods) and refinement (full-matrix least-squares methods on $\mathrm{F}^{2}$ ). Anisotropic displacement parameters were applied to all non-hydrogen atoms. $\mathrm{H}$ atoms $\left(\mathrm{U}_{\text {iso }}\right)$ were obtained from difference Fourier maps. HFIX geometrical constraints were applied only for C-H bonds. Additional software: Mercury [81]; PLATON [82]. CCDC deposition numbers: CCDC 1905722 for 1, CCDC 1905723 for 2, CCDC 1905724 for 3, and CCDC 1905725 for 4. 
Table 2. Crystallographic data and processing parameters.

\begin{tabular}{lcccc}
\hline \multicolumn{1}{c}{ Compound } & $\mathbf{1}$ & $\mathbf{2}$ & $\mathbf{3}$ & $\mathbf{4}$ \\
\hline Empirical formula & $\mathrm{C}_{16} \mathrm{H}_{14} \mathrm{CoN}_{8} \mathrm{O}_{4}$ & $\mathrm{C}_{16} \mathrm{H}_{14} \mathrm{MnN}_{8} \mathrm{O}_{4}$ & $\mathrm{C}_{16} \mathrm{H}_{14} \mathrm{CdN}_{8} \mathrm{O}_{4}$ & $\mathrm{C}_{16} \mathrm{H}_{14} \mathrm{CuN}_{8} \mathrm{O}_{4}$ \\
Formula mass & 441.28 & 437.29 & 494.76 & 445.90 \\
System & Monoclinic & Orthorhombic & Orthorhombic & Monoclinic \\
Space group & $\mathrm{P} 2{ }_{1} / \mathrm{c}$ & $\mathrm{P}{ }_{1}{ }_{1} 2$ & Pccn & $\mathrm{P} 2_{1} / \mathrm{c}$ \\
$\mathrm{a}(\AA)$ & $7.3603(4)$ & $18.2240(7)$ & $17.7537(7)$ & $11.0685(5)$ \\
$\mathrm{b}(\AA)$ & $6.6096(5)$ & $6.6283(3)$ & $6.6690(3)$ & $6.0407(2)$ \\
$\mathrm{c}(\AA)$ & $18.4806(13)$ & $7.5065(3)$ & $15.2622(6)$ & $13.4842(5)$ \\
$\beta\left({ }^{\circ}\right)$ & $101.257(4)$ & 90 & 90 & $91.770(2)$ \\
$\mathrm{V}\left(\AA^{3}\right)$ & $881.76(10)$ & $906.74(6)$ & $1807.04(13)$ & $901.14(6)$ \\
$\mathrm{Z}$ & 2 & 2 & 4 & 2 \\
$\mathrm{~T}(\mathrm{~K})$ & $100(2)$ & $100(2)$ & $100(2)$ & $100(2)$ \\
$\left.\mu(\mathrm{mm})^{-1}\right)$ & 1.018 & 0.772 & 1.253 & 1.256 \\
$\mathrm{D}_{\text {calc }}\left(\mathrm{Mg} / \mathrm{m}^{3}\right)$ & 1.662 & 1.602 & 1.819 & 1.643 \\
$\theta$ max $\left({ }^{\circ}\right)$ & 30.598 & 30.092 & 29.998 & 30.148 \\
Data collected & 38338 & 29257 & 70221 & 48444 \\
Unique refl. & 2707 & 2662 & 2648 & 2643 \\
$\mathrm{R}_{\text {int }}$ & 0.0547 & 0.0522 & 0.0378 & 0.0306 \\
Parameters & 134 & 134 & 133 & 171 \\
GooF on F & 1.058 & 1.134 & 1.105 & 1.092 \\
$\mathrm{R} 1(\mathrm{I}>2(\sigma \mathrm{I}))$ & 0.0282 & 0.0276 & 0.0189 & 0.0219 \\
wR2 $($ all data) & 0.0699 & 0.0653 & 0.0431 & 0.0619 \\
Residual extrema $\left(\mathrm{e} / \AA^{3}\right)$ & $0.43 /-0.42$ & $0.45 /-0.40$ & $0.41 /-0.68$ & $0.44 /-0.37$ \\
\hline
\end{tabular}

\subsection{The Computational Methodology}

Using Gaussview 6.0 [83], three model metal (II) dicyanamido (dca) complexes, as depicted in Figure 9, were constructed in order to describe the oligomeric bonding via the bridging ligand. The three structures are distinguishable by the metal(II) centers (Co, Mn, or Cd) and are consistent with those studied herein. As our interest is in the inherent connectivity of the dca unit, each of the three structures was terminated by an inert and benign carbonyl moiety, as shown in Figure 9 . Using Gaussian 16 [83], the ground state minimum energy geometry of each of the three complexes was optimized using density functional theory (DFT), with the Becke-3rd Parameter-Lee-Yang-Parr (B3LYP) functional [84], coupled to the LANL2DZ [85] basis set. Potential energy (PE) profiles were computed along the oxygen-metal-metal-oxygen dihedral (see molecular inset in Figure 10; henceforth $\phi)$ in order to reveal the optimal orientation of the ligands with respect to the dca-bridge. The same level of theory as shown above was used for the PE profiles.

Supplementary Materials: The following are available online at http://www.mdpi.com/2312-7481/5/3/41/s1, Figure S1-S4: IR spectra of 1-4 compounds, respectively, Figure S5-S7. UV-VIS-NIR spectra of 1, 2 and 4 compounds, respectively, Figure S8-S11. Observed and simulated X-ray powder pattern of 1-4, Table S1: The groud state minimum energy of $\mathrm{Co}(\mathrm{II})$ or $\mathrm{Mn}(\mathrm{II})$ centers of 1 and 2, respectively in their high-spin and low-spin configurations.

Author Contributions: F.A.M., R.C.F. and A.T. performed the X-ray structural analysis. F.A.M. and P.J. contributed to the synthesis and spectral characterization of the compounds. R.V. was in charge of the magnetic study and T.N.V.K. performed the computational study. F.A.M., R.V. and S.S.M. contributed in analyzing the data and writing the manuscript.

Funding: Financial aid come from DGICT Project CTQ2015-63614-P and the department of chemistry at UL Lafayette by S.S.M.

Acknowledgments: F.A.M. is thankful for K. Gatterer. Financial aid from DGICT Project CTQ2015-63614-P is acknowledged by R.V.; and from the department of chemistry at UL Lafayette by S.S.M.

Conflicts of Interest: The authors declare no conflict of interest. 


\section{References}

1. Yang, S.-H.; Liu, L.-J.; Ju, H.-Y.; Liu, X.-Y.; Li, Y.-G.; Yan, S.-P. Dicyanamide bridged Cu(II)-metallacrown-6 complex with 1,4,7-triisopropyl-1,4,7-triaza-cyclononane and binding properties with DNA. Molecules 2018, 23, 1269. [CrossRef]

2. Mautner, F.A.; Traber, M.; Jantscher, P.; Fischer, R.C.; Reichmann, K.; Vicente, R.; Arafat, N.; Massoud, S.S. Thiocyanato-metal(II) and azido-cobalt(III) complexes with hydroxymethylpyridines. Polyhedron 2019, 161, 309-316. [CrossRef]

3. Mautner, F.A.; Fischer, R.C.; Torvisco, A.; Henary, M.M.; Milner, A.; DeVillier, H.; Karsili, T.N.V.; Louka, F.R.; Massoud, S.S. Steric effects of alkyl substituents at N-donor bidentate amines direct the nuclearity, bonding and bridging modes in isothiocyanato-copper(II) coordination compounds. Crystals 2019, 9, 38. [CrossRef]

4. Mautner, F.A.; Traber, M.; Fischer, R.C.; Torvisco, A.; Reichmann, K.; Speed, S.; Vicente, R.; Massoud, S.S. Synthesis and structural characterization of thiocyanato-4-methoxypyridine-cobalt(II) complexes with diverse geometries and a bridged 1D coordination polymer showing metamagnetic transition. Polyhedron 2018, 154, 436-442. [CrossRef]

5. Massoud, S.S.; Henary, M.M.; Maxwell, L.; Martín, A.; Ruiz, E.; Vicente, R.; Fischer, R.C.; Mautner, F.A. Structure, magnetic properties and DFT calculations of azido-copper(II) complexes with different azido-bonding, nuclearity and dimensionality. New J. Chem. 2018, 42, 2627-2639. [CrossRef]

6. Wöhlert, S.; Ruschewitz, U.; Näther, C. Metamagnetism and slow relaxation of the magnetization in the 2D coordination polymer: [Co(NCSe) 2 (1,2-bis(4-pyridyl)ethylene) $]_{n}$. Cryst. Growth Des. 2018, 12, 2715-2718. [CrossRef]

7. Mautner, F.A.; Berger, C.; Fischer, R.C.; Massoud, S.S.; Vicente, R. Synthesis, structural characterization and magnetic properties of polymeric azido $\mathrm{Mn}(\mathrm{II})$ complexes based on methylpyridine- $\mathrm{N}$-oxide co-ligands. Polyhedron 2017, 134, 126-134. [CrossRef]

8. Escuer, A.; Esteban, J.; Perlepes, S.P.; Stamatatos, T.C. The bridging azido ligand as a central "player" in high-nuclearity 3d-metal cluster chemistry. Coord. Chem. Rev. 2014, 275, 87-129. [CrossRef]

9. Mautner, F.A.; Fischer, R.C.; Reichmann, K.; Gullett, E.; Ashkar, K.; Massoud, S.S. Synthesis and characterization of $1 \mathrm{D}$ and 2D cadmium(II)-2,2'-bipyridine-N,N'-dioxide coordination polymers bridged by pseudohalides. J. Mol. Struct. 2019, 1175, 797-803. [CrossRef]

10. Mautner, F.A.; Traber, M.; Fischer, R.C.; Massoud, S.S.; Vicente, R. Synthesis, crystal structures, spectral and magnetic properties of 1-D polymeric dicyanamido metal(II) complexes. Polyhedron 2017, 138, 13-20. [CrossRef]

11. Massoud, S.S.; Lemieux, M.C.; Le Quan, L.L.; Vicente, R.; Albering, J.H.; Mautner, F.A. Dicyanamido-metal(II) complexes. Part 6: 1-D polymeric copper(II) complexes bridging by dicyanamide. Effect of copper(II) salt on the nature of the polymeric product. Inorg. Chim. Acta 2012, 388, 71-77. [CrossRef]

12. Mautner, F.A.; Albering, J.H.; Mikuriya, M.; Massoud, S.S. Dicyanamido-metal(II) complexes. Part 5: First example for a unit cell containing dinuclear and 1-D polymeric $\mathrm{Cu}(\mathrm{II})$ complexes bridging by dicyanamide. Inorg. Chem. Commun. 2010, 13, 796-799. [CrossRef]

13. Mautner, F.A.; Mikuriya, M.; Ishida, H.; Louka, F.R.; Humphrey, J.W.; Massoud, S.S. Dicyanamido-metal(II) complexes. Part 4. Synthesis, structure and magnetic characterization of polynuclear $\mathrm{Cu}(\mathrm{II})$ and $\mathrm{Ni}(\mathrm{II})$ complexes bridged by $\mu$-1,5-dicyanamide. Inorg. Chim. Acta 2009, 362, 4073-4080. [CrossRef]

14. Batten, R.S.; Murray, K.S. Structure and magnetism of coordination polymers containing dicyanamide and tricyanomethanide. Coord. Chem. Rev. 2003, 246, 103-130. [CrossRef]

15. Chakraborty, P.; Mondal, S.; Das, S.; Jana, A.D.; Das, D. Dicyanamide mediated construction of 1D polymeric networks of quinoxaline with $\mathrm{d}^{10}$ metal ions: Synthesis, thermogravimetric analysis, photoluminescence and a theoretical investigation on the $\pi-\pi$ interactions. Polyhedron 2014, 70, 11-19. [CrossRef]

16. Banerjee, S.; Halder, S.; Brandao, P.; Gomez Garcia, C.J.; Benmansour, S.; Saha, A. Synthesis and characterization of a novel dicyanamide-bridged Co(II) 1-D coordination polymer with a N4-donor Schiff base ligand. Inorg. Chim. Acta 2017, 464, 65-73. [CrossRef]

17. Zheng, L.L.; Zhou, C.X.; Hu, S.; Zhou, A.J. Structural diversification of coordination assemblies of $\mathrm{M}^{\mathrm{II}}$-dca-hydroxylpyridine (dca = dicyanamide). Polyhedron 2016, 104, 91-98. [CrossRef] 
18. Jensen, P.; Batten, S.R.; Moubaraki, B.; Murray, K.S. Infinite molecular tubes: Structure and magnetism of $\mathrm{M}(\mathrm{dca})_{2}(\mathrm{apym})\left[\mathrm{M}=\mathrm{Co}, \mathrm{Ni}\right.$, apym $=2$-aminopyrimidine, dca $=$ dicyanamide, $\left.\mathrm{N}(\mathrm{CN})_{2}{ }^{-}\right]$. Chem. Commun. 2000, 9, 793-794. [CrossRef]

19. Jensen, P.; Price, D.J.; Batten, S.R.; Moubaraki, B.; Murray, K.S. Self-penetration-A structural compromise between single Networks and interpenetration: Magnetic properties and crystal structures of $\left[\mathrm{Mn}(\mathrm{dca})_{2}\left(\mathrm{H}_{2} \mathrm{O}\right)\right]$ and $[\mathrm{M}(\mathrm{dca})(\mathrm{tcm})], \mathrm{M}=\mathrm{Co}, \mathrm{Ni}, \mathrm{Cu}, \mathrm{dc}$ a $=$ Dicyanamide, $\mathrm{N}(\mathrm{CN})_{2}{ }^{-}, \mathrm{tcm}=$ tricyanomethanide, $\mathrm{C}(\mathrm{CN})_{3}{ }^{-}$. Chem. Eur. J. 2000, 6, 3186-3195. [CrossRef]

20. Zheng, L.-L.; Leng, J.-D.; Liu, W.-T.; Zhang, W.-X.; Lu, J.-X.; Tong, M.-L. Cu ${ }^{2+}$-Mediated nucleophilic addition of different nucleophiles to dicyanamide-Synthesis, structures, and magnetic properties of a family of mononuclear, trinuclear, hexanuclear, and polymeric copper(II) complexes. Eur. J. Inorg. Chem. 2008, 2008, 4616-4624. [CrossRef]

21. Vangdal, B.; Carranza, C.; Lloret, F.; Julve, M.; Sletten, J.J. Syntheses, crystal structures and magnetic properties of copper(II) dicyanamide complexes; dinuclear, chain and ladder compounds. Chem. Soc. Dalton Trans. 2002, 4, 566-574. [CrossRef]

22. Genre, C.; Jeanneau, E.; Bousseksou, A.; Luneau, D.; Borshch, S.A.; Galina, S.; Matouzenko, G.S. First dicyanamide-bridged spin-crossover coordination polymer: Synthesis, structural, magnetic, and spectroscopic studies. Chem. A Eur. J. 2008, 40, 697-705. [CrossRef] [PubMed]

23. Carranza, J.C.; Brennan, C.; Sletten, J.; Lloret, F.; Julve, M.J. Three one-dimensional systems with end-to-end dicyanamide bridges between copper(II) centres: Structural and magnetic properties. Chem. Soc. Dalton Trans. 2002, 16, 3164-3170. [CrossRef]

24. Armentano, D.; De Munno, G.; Guerra, F.; Julve, M.; Lloret, F. Ligand effects on the structures of extended networks of dicyanamide-containing transition-metal ions. Inorg. Chem. 2006, 45, 4626-4636. [CrossRef] [PubMed]

25. Van Albada, G.A.; van der Horst, M.G.; Teat, S.J.; Gamez, P.; Roubeau, O.; Mutikainen, I.; Turpeinen, U.; Reedijk, J. Polynuclear $\mathrm{Cu}(\mathrm{II}), \mathrm{Ni}(\mathrm{II})$ and $\mathrm{Cd}(\mathrm{II})$ coordination compounds with bis(pyrimidin-2-yl)amine and dicyanamide. Polyhedron 2009, 28, 1541-1545. [CrossRef]

26. Ghosh, T.; Chattopadhyay, T.; Das, S.; Mondal, S.; Suresh, E.; Zangrando, E.; Das, D. Thiocyanate and dicyanamide anion controlled nuclearity in $\mathrm{Mn}, \mathrm{Co}, \mathrm{Ni}, \mathrm{Cu}$, and $\mathrm{Zn}$ metal complexes with hemilabile ligand 2-benzoylpyridine. Cryst. Growth Des. 2011, 11, 3198-3205. [CrossRef]

27. Halder, G.J.; Kepert, C.J.; Moubaraki, B.; Murray, K.S.; Cashion, J.D. Guest-dependent spin crossover in a nanoporous molecular framework material. Science 2002, 298, 1762-1765. [CrossRef] [PubMed]

28. Gong, Y.N.; Huang, Y.L.; Jiang, L.; Lu, T.-B. A luminescent microporous metal-organic framework with highly selective $\mathrm{CO}_{2}$ adsorption and sensing of nitro explosives. Inorg. Chem. 2014, 53, 9457-9459. [CrossRef]

29. Getman, R.B.; Bae, Y.-S.; Wilmer, C.E.; Snurr, R.Q. Review and analysis of molecular simulations of methane, hydrogen, and acetylene storage in metal-organic frameworks. Chem. Rev. 2012, 112, 703-723. [CrossRef]

30. Rao, C.N.R.; Ranganathan, A.; Pedireddi, V.R.; Raju, A.R. A novel hybrid layer compound containing silver sheets and an organic spacer. Chem. Commun. 2000, 1, 39-40. [CrossRef]

31. Ruben, M.; Lehn, J.-M.; Vaughan, G. Synthesis of ionisable [2 $\times 2$ ] grid-type metallo-arrays and reversible protonic modulation of the optical properties of the $\left[\mathrm{Co}_{4}{ }_{4} \mathrm{~L}_{4}\right]^{8+}$ species. Chem. Commun. 2003, 12, 1338-1339. [CrossRef]

32. Ivanova, B.; Spiteller, M. $\mathrm{Ag}^{\mathrm{I}}$ and $\mathrm{Zn}^{\mathrm{II}}$ complexes with possible application as NLO materials-Crystal structures and properties. Polyhedron 2011, 30, 241-245. [CrossRef]

33. Ma, L.-F.; Wang, L.-Y.; Wang, Y.-Y.; Batten, S.R.; Wang, J.-G. Self-assembly of a series of cobalt(II) coordination polymers constructed from $\mathrm{H}_{2}$ tbip and dipyridyl-based ligands. Inorg. Chem. 2009, 48, 915-924. [CrossRef] [PubMed]

34. Lv, R.; Li, H.; Su, J.; Fu, X.; Yang, B.; Gu, W.; Liu, X. Zinc metal-organic framework for selective detection and differentiation of Fe(III) and $\mathrm{Cr}(\mathrm{VI})$ ions in aqueous solution. Inorg. Chem. 2017, 56, 12348-12356. [CrossRef] [PubMed]

35. Mal, D.; Sen, R.; Brandao, P.; Lin, Z. Crystallization of five new supramolecular networks with both bipyridyl and dicyanamide ligands. Polyhedron 2013, 53, 249-257. [CrossRef]

36. Mautner, F.A.; Berger, C.; Fischer, R.C.; Massoud, S.S. Synthesis, characterization and luminescence properties of zinc(II) and cadmium(II) pseudohalide complexes derived from quinoline-N-oxide. Inorg. Chim. Acta 2016, 439, 69-76. [CrossRef] 
37. Evans, O.R.; Lin, W. Crystal engineering of NLO materials based on metal-organic coordination networks. Acc. Chem. Res. 2002, 35, 511-522. [CrossRef]

38. Kahn, O. Chemistry and physics of supramolecular magnetic materials. Acc. Chem. Res. 2000, 33, 647-657. [CrossRef]

39. Yang, G.-S.; Liu, C.B.; Liu, H.; Robbins, J.; Zhang, Z.J.; Yin, H.S.; Wen, H.-L.; Wang, Y.-H. Rational assembly of $\mathrm{Pb}(\mathrm{II}) / \mathrm{Cd}(\mathrm{II}) / \mathrm{Mn}(\mathrm{II})$ coordination polymers based on flexible V-shaped dicarboxylate ligand: Syntheses, helical structures and properties. J. Solid State Chem. 2015, 225, 391-401. [CrossRef]

40. Qiao, J.-Z.; Zhan, M.-S.; Hu, T.-P. Syntheses, crystal structures, photoluminescent/magnetic properties of four new coordination polymers based on 2,3' ,4,5'-biphenyltetracarboxylic acid. RSC Adv. 2014, 4, 62285-62294. [CrossRef]

41. Mautner, F.A.; Soileau, J.B.; Bankole, P.K.; Gallo, A.; Massoud, S.S. Synthesis and spectroscopic characterization of dicyanamido- $\mathrm{Cu}(\mathrm{II})$ complexes. Part 2. Crystal structure of the complexes of tris[2-(2-pyridylethyl)]amine, tris(2-pyridylmethyl)amine and 1,4-bis[2-(2-pyridylethyl)]-piperazine. J. Mol. Struct. 2008, 889, 271-278. [CrossRef]

42. Sun, H.-L.; Gao, S.; Ma, B.-Q.; Su, G. Long-range ferromagnetic ordering in two-dimensional coordination polymers $\mathrm{Co}\left[\mathrm{N}(\mathrm{CN})_{2}\right]_{2}(\mathrm{~L})[\mathrm{L}=$ pyrazine dioxide (pzdo) and 2-methyl pyrazine dioxide (mpdo)] with dual $\mu$ and $\mu 3-\left[\mathrm{N}(\mathrm{CN})_{2}\right.$ ] bridges. Inorg. Chem. 2003, 42, 5399-5404. [CrossRef] [PubMed]

43. Costes, J.-P.; Novitchi, G.; Shova, S.; Dahan, F.; Donnadieu, B.; Tuchagues, J.-P. Synthesis, structure, and magnetic properties of heterometallic dicyanamide-bridged $\mathrm{Cu}-\mathrm{Na}$ and $\mathrm{Cu}-\mathrm{Gd}$ one-dimensional polymers. Inorg. Chem. 2004, 43, 7792-7799. [CrossRef] [PubMed]

44. Yang, E.-C.; Liu, Z.-Y.; Chen, S.-H.; Su, Y.-H.; Zhang, Y.-Y.; Zhao, X.-J. Four linear Cu ${ }^{\mathrm{II}}{ }_{3}$ subunit-based coordination polymers with various inter-subunit connections, spin ground-states and intra-/inter-subunit magnetic couplings. Dalton Trans. 2015, 44, 3190-3199. [CrossRef] [PubMed]

45. El Fallah, M.S.; Badyine, F.; Vicente, R.; Escuer, A.; Solans, X.; Font-Bardia, M. Complementarity and countercomplementarity in polynuclear copper(II) complexes with $\mathrm{R}_{2} \mathrm{NCH}_{2} \mathrm{CH}(\mathrm{OH}) \mathrm{CH}_{2} \mathrm{NR}_{2}\left(\mathrm{R}=\mathrm{H}, \mathrm{CH}_{3}\right)$ : Crystal structures and magnetic study. Dalton Trans. 2002, 2934-2942. [CrossRef] [PubMed]

46. Batten, S.R.; Jensen, P.; Moubaraki, B.; Murray, K.S. Anionic metal dicyanamide networks with paramagnetic counter-cations. Chem. Commun. 2000, 23, 2331-2332. [CrossRef]

47. Miller, J.S.; Manson, J. Designer magnets containing cyanides and nitriles. Acc. Chem. Res. 2001, 34, 563-570. [CrossRef] [PubMed]

48. Manson, J.L.; Huang, Q.-Z.; Lynn, J.W.; Koo, H.-J.; Whangbo, M.H.; Bateman, R.; Otsuka, T.; Wada, N.; Argyriou, D.N.; Miller, J.S. Long-range magnetic order in $\mathrm{Mn}\left[\mathrm{N}(\mathrm{CN})_{2}\right]_{2}(\mathrm{pyz})\{\mathrm{pyz}=$ pyrazine $\}$. Susceptibility, magnetization, specific heat, and neutron diffraction measurements and electronic structure calculations. $J$. Am. Chem. Soc. 2001, 123, 162-172. [CrossRef] [PubMed]

49. Schlueter, J.A.; Manson, J.L.; Geiser, U. Structural and magnetic diversity in tetraalkylammonium salts of anionic $\mathrm{M}\left[\mathrm{N}(\mathrm{CN})_{2}\right]_{3}{ }^{-}(\mathrm{M}=\mathrm{Mn}$ and $\mathrm{Ni})$. Three-dimensional coordination polymers. Inorg. Chem. 2005, 44, 3194-3202.

50. Kutasi, A.M.; Batten, S.R.; Moubaraki, B.; Murray, K.S. New 2D coordination polymers containing both biand tri-dentate dicyanamide bridges and intercalated phenazine. J. Chem. Soc. Dalton Trans. 2002, 6, 819-821. [CrossRef]

51. Manson, J.L.; Gu, J.; Wang, H.-H.; Schlueter, J.A. Structures and magnetic behavior of 1-, 2-, and 3D coordination polymers in the $\mathrm{Cu}(\mathrm{II})$-dicyanamide-pyrimidine family. Inorg. Chem. 2003, 42, 3950-3955. [CrossRef] [PubMed]

52. Talukder, P.; Shit, S.; Sasmal, A.; Batten, S.R.; Moubaraki, B.; Murray, K.S.; Mitra, S. An antiferromagnetically coupled hexanuclear copper(II) Schiff base complex containing phenoxo and dicyanamido bridges: Structural aspects and magnetic properties. Polyhedron 2011, 30, 1767-1773. [CrossRef]

53. Sen, R.; Bhattacharjee, A.; Gutlich, P.; Miyashita, Y.; Okamoto, K.-I.; Koner, S. Structural and magnetic diversity in metal-dicyanamido polymer moieties: Paramagnetic and antiferromagnetic 1D chain compound and weakly ferromagnetic 2D motif. Inorg. Chim. Acta 2009, 362, 4663-4670. [CrossRef]

54. Mautner, F.A.; Berger, C.; Fischer, R.C.; Massoud, S.S.; Vicente, R. Synthesis, structural characterization and magnetic properties of $\mathrm{Mn}(\mathrm{II})$ isothiocyanate complexes based on pyridine- $\mathrm{N}$-oxide derivative co-ligands. Polyhedron 2018, 141, 17-24. [CrossRef] 
55. Luo, Y.-H.; Ma, Y.-T.; Bao, Q.-Q.; Sun, B.-W. Syntheses, crystal structure and properties of two 1-D coordination polymers bridged by dicyanamides. J. Chem. Crystallogr. 2012, 42, 628-632. [CrossRef]

56. Sun, B.-W.; Gao, S.; Ma, B.-Q.; Niu, D.-Z.; Wang, Z.-M. Syntheses, structures and magnetic properties of three-dimensional co-ordination polymers constructed by dimer subunits. J. Chem. Soc. Dalton Trans. 2000, 22, 4187-4191. [CrossRef]

57. Ghoshal, D.; Mostafa, G.; Maji, T.K.; Zangrando, E.; Lu, T.-H.; Ribas, J.; Chaudhuri, N.R. Synthesis, crystal structure and magnetic behavior of three polynuclear complexes: $\left[\mathrm{Co}(\mathrm{pyo})_{2}(\mathrm{dca})_{2}\right]_{\mathrm{n}}$, $\left[\mathrm{Co}_{3}(\mathrm{ac})_{4}(\mathrm{bpe})_{3}(\mathrm{dca})_{2}\right]_{\mathrm{n}}$ and $\left[\left\{\mathrm{Co}(\mathrm{male})\left(\mathrm{H}_{2} \mathrm{O}\right)_{2}\right\}\left(\mathrm{H}_{2} \mathrm{O}\right)\right]_{\mathrm{n}}$ [pyo, pyridine-N-oxide; dca, dicyanamide; ac, acetate; bpe, 1,2-bis-(4-pyridyl)ethane and male, maleate]. New J. Chem. 2004, 28, 1204-1213.

58. Van Albada, G.A.; Mutikainen, I.; Turpeinen, U.; Reedijk, J. A rare 2D structure of a novel Cu(II) dinuclear-based compound with dicyanamide and 4-nitropyridine-N-oxide as ligands. Inorg. Chem. Commun. 2006, 9, 441-443. [CrossRef]

59. Hnatejko, Z.; Kwiatek, D.; Durkiewicz, G.; Kubicki, M.; Jastrazab, R.; Lis, S. Pyridine N-oxide complexes of $\mathrm{Cu}(\mathrm{II})$ ions with pseudohalides: Synthesis, structural and spectroscopic characterization. Polyhedron 2014, 81, 728-734. [CrossRef]

60. Manson, J.L.; Lee, D.W.; Rheingold, A.L.; Miller, J.S. Buckled-layered Structure of Zinc Dicyanamid, $\mathrm{Zn}^{\mathrm{II}}\left[\mathrm{N}(\mathrm{CN})_{2}\right]_{2}$. Inorg. Chem. 1998, 37, 5966-5967. [CrossRef]

61. Köhler, H.; Kolbe, A.; Lux, G.Z. Metal-pseudohalogenide 27. Zur struktur der dicyanamide zweiwertiger 3d-metalle $\mathrm{M}\left(\mathrm{N}(\mathrm{CN})_{2}\right)_{2}$. Anorg. Allg. Chem. 1977, 428, 103-112. [CrossRef]

62. Hathaway, B.J. Comprehensive Coordination Chemistry; Wilkinson, G., Gillard, R.D., McCleverty, J.A., Eds.; Pergamon Press: Oxford, UK, 1987; Volume 5, p. 533.

63. Mautner, F.A.; Jantscher, P.; Fischer, R.C.; Torvisco, A.; Vicente, R.; Karsili, T.N.V.; Massoud, S.S. Synthesis and characterization of 1D coordination polymers of metal(II)-dicyanamido complexes. Polyhedron 2019, 166, 34-43. [CrossRef]

64. Claramunt, A.; Escuer, A.; Mautner, F.A.; Sanz, N.; Vicente, R.J. Two new one-dimensional systems with end-to-end single dicyanamide bridges between manganese(II) centres: Structural and magnetic properties. Chem. Soc. Dalton Trans. 2000, 15, 2627-2630. [CrossRef]

65. Manson, J.L.; Schlueter, J.A.; Nygren, C.L. $\mathrm{Mn}(\mathrm{dca})_{2}(\mathrm{pym})_{2}$ and $\mathrm{Mn}(\mathrm{dca})_{2}(\mathrm{pym})\left(\mathrm{H}_{2} \mathrm{O}\right)\{$ dca $=$ dicyanamide; pym = pyrimidine\}: New coordination polymers exhibiting 1- and 2-D topologies. Dalton Trans. 2007, 646-652. [CrossRef] [PubMed]

66. Wriedt, M.; Näther, C. Directed synthesis of $\mu-1,3,5$ bridged dicyanamides by thermal decomposition of $\mu-1,5$ bridged precursor compounds. Dalton Trans. 2011, 40, 886-898. [CrossRef] [PubMed]

67. De la Pinta, N.; Martín, S.; Urtiaga, M.K.; Barandika, M.G.; Arriortua, M.I.; Lezama, I.; Madariaga, G.; Cortés, R. Structural analysis, spectroscopic, and magnetic properties of the $1 \mathrm{D}$ triple-bridged compounds $\left[\mathrm{M}(\mathrm{dca})_{2}(\mathrm{bpa})\right](\mathrm{M}=\mathrm{Mn}, \mathrm{Fe}, \mathrm{Co}, \mathrm{Zn}$; dca = dicyanamide; bpa = 1,2-bis(4-pyridyl)ethane) and the 3D [Ni(dca)(bpa $)_{2}$ ]dca $6 \mathrm{H}_{2} \mathrm{O}$. Inorg. Chem. 2010, 49, 10445-10454. [CrossRef] [PubMed]

68. Das, A.; Marschner, C.; Cano, J.; Baumgartner, J.; Ribas, J.; El Fallah, M.S.; Mitra, S. Synthesis, crystal structures and magnetic behaviors of two dicyanamide bridged di- and polynuclear complexes of cobalt(II) derived from 2,4,6-tris(2-pyridyl)1,3,5-triazine and imidazole. Polyhedron 2009, 28, 2436-2442. [CrossRef]

69. Fisher, M.E. Perpendicular susceptibility of the Ising model. J. Math. Phys. 1963, 4, 124-135. [CrossRef]

70. Fisher, M.E. Magnetism in one-dimensional systems-the Heisenberg model for infinite spin. Am. J. Phys. 1964, 32, 343-346. [CrossRef]

71. Escuer, A.; Mautner, F.A.; Sanz, N.; Vicente, R. Syntheses, structures and magnetic properties of the dicyanamide (dca) polynuclear compounds $\left[\mathrm{Mn}(\mathrm{ac})\left(\text { terpy) }\left(\mu_{1,5}-\mathrm{dca}\right)\right]_{\mathrm{n}},\left[\mathrm{Mn}(\mathrm{pdz})_{2}\left(\mu_{1,5}-\mathrm{dca}\right)_{2}\right]_{\mathrm{n}}\right.$ and [\{Mn(dca)(terpy)-(MeOH) $\}_{2}$ ( $\mu$-terephthalate)]. Inorg. Chim. Acta 2002, 340, 163-169. [CrossRef]

72. Biswas, M.; Rosair, G.M.; Pilet, G.M.; Mitra, S. Syntheses, structures and magnetic properties of $\left[\mathrm{M}^{\mathrm{II}}(\mathrm{dca})_{2}\left(\mathrm{CH}_{3} \mathrm{OH}\right)_{2}\right]_{\mathrm{n}}$, where $\mathrm{M}=\mathrm{Co}$ or $\mathrm{Cu}$ and $\mathrm{dca}=$ dicyanamide, $\mathrm{N}(\mathrm{CN})_{2}{ }^{-}$. Inorg. Chim. Acta 2007, 360, 695-699. [CrossRef]

73. Van Albada, G.A.; Quiroz-Castro, M.E.; Mutikainen, I.; Turpeinen, U.; Reedijk, J. The first structural evidence of a polymeric $\mathrm{Cu}$ (II) compound with a bridging dicyanamide anion: X-ray structure, spectroscopy and magnetism of catena-[polybis(2-aminopyrimidine)copper(II)bis( $\mu$-dicyanamido)]. Inorg. Chim. Acta 2000, 298, 221-225. [CrossRef] 
74. Zhang, X.; Li, B.; Zhang, J. An efficient strategy for self-assembly of DNA-mimic homochiral 1D helical Cu(II) chain from achiral flexible ligand by spontaneous resolution. Inorg. Chem. 2016, 55, 3378-3383. [CrossRef] [PubMed]

75. Shi, W.B.; Cui, A.L.; Kou, H.Z. Assembly of dinuclear copper(II) secondary building units into polymeric complexes: Crystal structures and magnetic properties. CrystEngComm 2014, 16, 8027-8034. [CrossRef]

76. Escuer, A.; Mautner, F.A.; Sanz, N.; Vicente, R. Two new one-dimensional compounds with end-to-end dicyanamide as a bridging ligand: syntheses and structural characterization of trans-[Mn(4-bzpy $\left.)_{2}\left(\mathrm{~N}(\mathrm{CN})_{2}\right)_{2}\right]_{\mathrm{n}}$ and cis-[Mn(Bpy) $\left.\left(\mathrm{N}(\mathrm{CN})_{2}\right)_{2}\right]_{\mathrm{n}}$, (4-bzpy = 4-benzoylpyridine; bpy = 2,2'-bipyridyl). Inorg. Chem. 2000, 39, 1668-1673. [CrossRef] [PubMed]

77. Bruker APEX, SAINT v. 8.37A; Bruker AXS Inc.: Madison, WI, USA, 2015.

78. Sheldrick, G.M. SADABS v. 2; University of Goettingen: Goettingen, Germany, 2001.

79. Sheldrick, G.M. A Short history of SHELX. Acta Crystallogr. A 2008, 64, 112-122. [CrossRef] [PubMed]

80. Sheldrick, G.M. Crystal structure refinement with SHELXL. Acta Crystallogr. C Struct. Chem. 2015, 71, 3-8. [CrossRef]

81. Macrae, C.F.; Edington, P.R.; McCabe, P.; Pidcock, E.; Shields, G.P.; Taylor, R.; Towler, T.; van de Streek, J.J. Mercury: Visualization and analysis of crystal structures. Appl. Cryst. 2006, 39, 453-457. [CrossRef]

82. Spek, A.L. PLATON, a Multipurpose Crystallographic Tool; Utrecht University: Utrecht, The Netherlands, 1999.

83. Frisch, M.J.; Trucks, G.W.; Schlegel, H.B.; Scuseria, G.E.; Robb, M.A.; Cheeseman, J.R.; Scalmani, G.; Barone, V.; Petersson, G.A.; Nakatsuji, H.; et al. Gaussian 16, Revision B.01; Gaussian Inc.: Wallingford, CT, USA, 2016.

84. Becke, A.D. Density-functional exchange-energy approximation with correct asymptotic behavior. Phys. Rev. A 1988, 38, 3098-3100. [CrossRef]

85. Hay, P.J.; Wadt, W.R. Ab initio effective core potentials for molecular calculations. Potentials for the transition metal atoms Sc to Hg. J. Chem. Phys. 1985, 82, 270-283. [CrossRef]

(C) 2019 by the authors. Licensee MDPI, Basel, Switzerland. This article is an open access article distributed under the terms and conditions of the Creative Commons Attribution (CC BY) license (http://creativecommons.org/licenses/by/4.0/). 